\title{
Feasibility of Using Acoustic Emission To Determine In-Process Tool Wear
}

Federal Manufacturing \& Technologies

L. J. Lazarus

KCP-613-5778

Published April 1996

RECEIVED

MAY 151996

OSTI

Final Report

Approved for public release; distribution is unlimited.

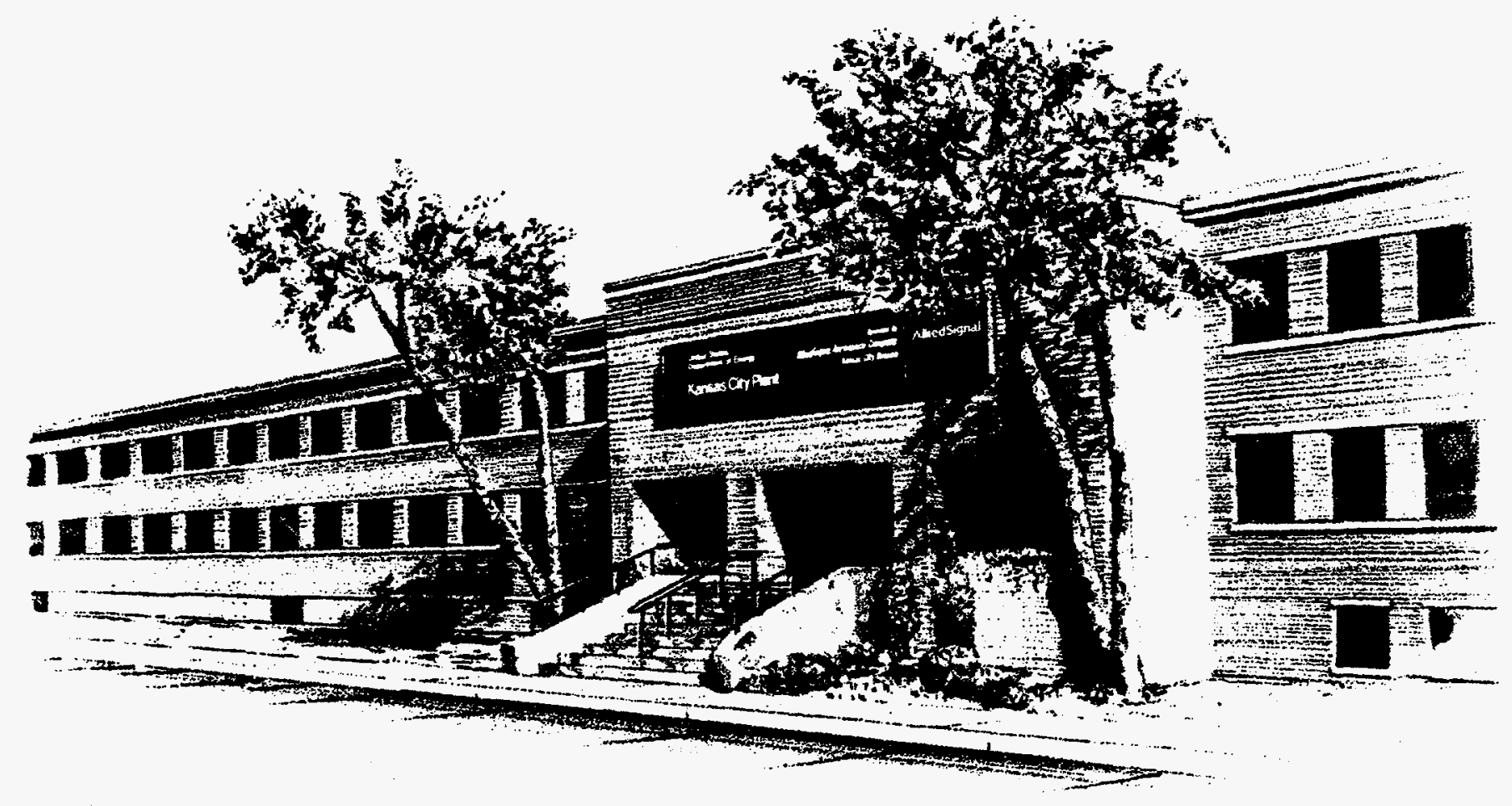

Prepared Under Contract Number DE-ACO4-76-DP00613 for the United States Department of Energy

AlliedSignal DISTAIBUTION OF THIS DOCUMENT IS UNLMITED

A E R O S P A C E MASTER 


\section{DISCLAIMER}

Portions of this document may be illegible in electronic image products. Images are produced from the best available original document. 


\section{DISCLAIMER}

This report was prepared as an account of work sponsored by an agency of the United States Government. Neither the United States Government nor any agency thereof, nor any of their employees, makes any warranty, express or implied, or assumes any legal liability or responsibility for the accuracy, completeness, or usefulness of any information, apparatus, product, or process disclosed, or represents that its use would not infringe privately owned rights. Reference herein to any specific commercial product, process, or service by trade names, trademark, manufacturer, or otherwise, does not necessarily constitute or imply its endorsement, recommendation, or favoring by the United States Government or any agency thereof. The views and opinions of authors expressed herein do not necessarily state or reflect those of the United States Government or any agency thereof.

All data prepared, analyzed and presented has been developed in a specific context of work and was prepared for internal evaluation and use pursuant to that work authorized under the referenced contract. Reference herein to any specific commercial product, process or service by trade name, trademark, manufacturer, or otherwise, does not necessarily constitute or imply its endorsement, recommendation, or favoring by the United States Government, any agency thereof or AlliedSignal Inc.

Printed in the United States of America.

This report has been reproduced from the best available copy. This document was reproduced from a previously published report.

Available to DOE and DOE contractors from the Office of Scientific and Technical Information, P. O. Box 62, Oak Ridge, Tennessee 37831; prices available from (615) 576-8401, FTS 626-8401.

Available to the public from the National Technical Information Service, U. S. Department of Commerce, 5285 Port Royal Rd., Springfield, Virginia 22161.

Copyright $\odot 1996$ by AlliedSignal Inc. The Government is granted for itself and others acting on its behalf a paid-up, nonexclusive, irrevocable worldwide license in this data to reproduce, prepare derivative works, and perform publicly and display publicly.

The Goverment reserves for itself and others acting on its behalf a royalty free, nonexclusive, irrevocable, world-wide license for govermental purposes to publish, distribute, translate, duplicate, exhibit, and perform any such data copyrighted by the contractor.

A prime contractor with the United States Department of Energy under Contract Number DE-ACO4-76-DP00613.
AlliedSignal Inc. Federal Manufacturing \& Technologies P. O. Box 419159 Kansas City, Missouri 64141-6159 
KCP-613-5778

Distribution Category UC-706

Approved for public release; distribution is unlimited.

\section{FEASIBILITY OF USING ACOUSTIC EMISSION} TO DETERMINE IN-PROCESS TOOL WEAR

\section{J. Lazarus}

Published April 1996

Final Report

L. J. Lazarus, Project Leader

Project Team:

R. J. Bossert

S. D. Nance 


\section{Contents}

Section

Abstract.

1

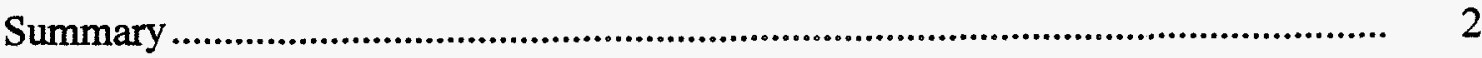

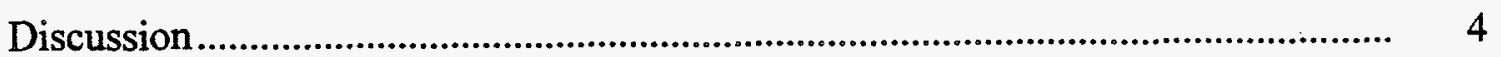

Scope and Purpose .................................................................................. 4

Prior Work ......................................................................................... 4

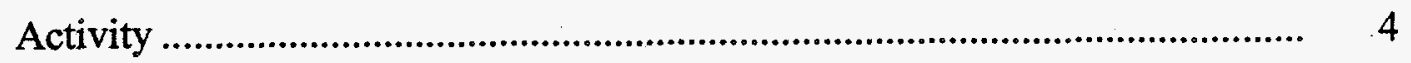

Background .............................................................................. 4

Literature Search...................................................................... 7

Experimental Activity ............................................................... 7

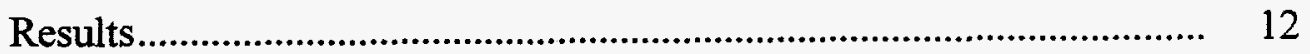

Accomplishments............................................................................. 16

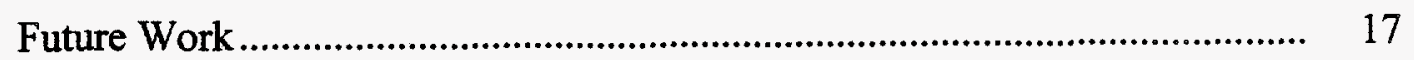

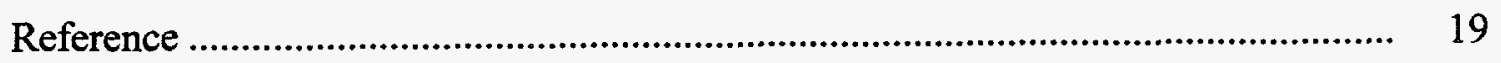

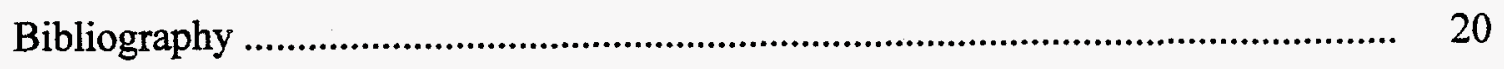

Appendices

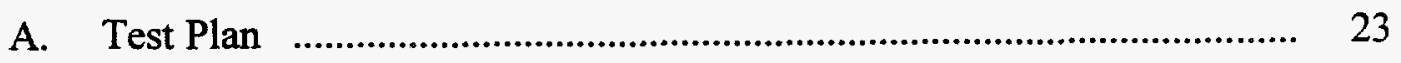

B. Acoustic Emission Screening Test Data ....................................... 25

C. Turning Test Data ......................................................................... 39

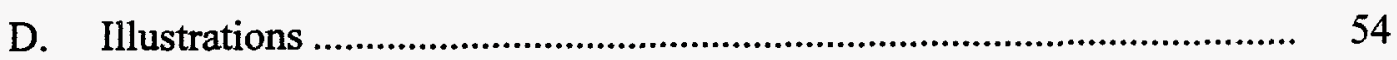




\section{Illustrations}

Figure

Page

D-1 Monarch Spindle Construction Showing AE Path................................... 55

D-2 Transducer Location on Courtland Mill ................................................. 56

D-3 Acoustic Emission and Thrust Load Output Versus Number of Holes Drilled AE Transducer on Resolver Mount .............................................. 57

D-4 Acoustic Emission and Thrust Load output Versus Number of Holes Drilled AE Transducer on Spindle Head ................................................... 58

D-5 Transducer Location on Thrust Table ................................................... 59

D-6 Acoustic Emission and Thrust Load Output Versus Number of Holes Drilled AE Transducer on Thrust Table ..................................................... $\quad 60$

D-7 Acoustic Emission Output Versus Distance From Transducer (Odd-Near, Even-Far), AE Transducer on Thrust Table.

D-8 Transducer Location on American Lathe 


\section{Tables}

Number Page

1 Acoustic Emission Drill Study 0.203 in. Diameter Drill ................................... 14

2 Acoustic Emission Drill Study 0.093 in. Diameter Drill .................................. 15

$3 \quad$ Acoustic Emission Drill Study 0.003 in. Diameter Drill .................................... 16

B-1 Acoustic Emission Statistical Screening Test 0.203 in. Diameter Drills Both Coated and Uncoated ..................................................................... 26

B-2 Acoustic Emission Preliminary Runs 0.203 in. Diameter Uncoated Speed Steel Drills Determination of Transducer Location ................................. $\quad 29$

B-3 Acoustic Emission Statistical Screening Test 0.033 in. Diameter Drills Both High Speed Steel and Carbide.

B-4 Acoustic Emission Statistical Screening Test 0.093 in. Diameter Drills Both High Speed Steel and Carbide.

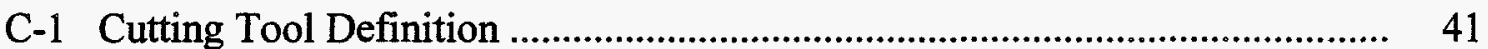




\begin{abstract}
Acoustic Emission (AE) was evaluated for its ability to predict and recognize failure of cutting tools during machining processes when the cutting tool rotates and the workpiece is stationary. $\mathrm{AE}$ output was evaluated with a simple algorithm. AE was able to detect drill failure when the transducer was mounted on the workpiece holding fixture. Drill failure was recognized as size was reduced to 0.003 in. diameter. The ability to predict failure was reduced with drill size, drill material elasticity, and tool coating. AE output for the turning process on a lathe was compared to turning tool insert wear. The turning tool must have sufficient wear to produce a detectable change in AE output to predict insert failure.
\end{abstract}


Acoustic Emission ( $\mathrm{AE}$ ) was evaluated for its ability to predict and recognize failure of cutting tools during the machining process. The ability to detect and predict in-process cutting tool failure based on the $\mathrm{AE}$ data and a simple algorithm was evaluated for drilling and turning.

Cutting tool monitors based on $\mathrm{AE}$ technology have recently been introduced in the market for lathes. Technical papers have been published on lathe applications and include theoretical models. There are no commercially available $\mathrm{AE}$ based machining monitors for machine tools where the workpiece material is stationary and the cutting tool rotates (drilling, milling, boring).

The $A E$ output for the drilling process was monitored on the Monarch Cortland Mill to determine the optimum location of the $\mathrm{AE}$ transducer. The best results are obtained when the $\mathrm{AE}$ transducer is mounted to the workpiece holding fixture. The $A E$ signal is greatly attenuated by traveling through the many interfaces that exist between the cutting tool and the machine tool frame.

A statistical screening test was used to determine the effects of decreasing drill size $(0.203,0.093,0.033$ in. diameter) and multiple tool materials (high speed steel and carbide) and/or tool coating (titanium nitrite). The change in $\mathrm{AE}$ output versus drill size was compared to a modified theoretical model to determine its appropriateness for this application.

The following conclusions were made. When the $A E$ transducer is incorporated into the holding fixture, $\mathrm{AE}$ could detect failure for all size drills tested. The ability to predict in-process cutting tool failure was affected by drill size, material and/or coating. $\mathrm{AE}$ was more sensitive to cutting tool deterioration than thrust load. The theoretical calculation changed the same percentage as the actual data; however, there was a large error in magnitude of the data.

Finally, an in-process turning test was monitored to determine the effects of turret location and tool wear on $\mathrm{AE}$ output. The data show that there must be sufficient wear of the turning insert to predict failure. Position of the lathe tool in the turret had no effect on the output of the AE transducer mounted on the turret. AE outputs were higher in turning than drilling.

AE technology presents an opportunity to develop a technique to predict cutting tool failure. AE can be applied to CNC Machining Centers when the transducer is incorporated into the design of the machining fixtures. This technology can be used with small size drills but great care must be taken with its application. 
Every tool type will require its own failure algorithm and the monitor must be sequenced with the CNC control. Additional investigative work is justified; but, more sophisticated equipment is necessary to allow artificial intelligence to be built into the monitor to predict failure. 


\section{DISCUSSION}

\section{SCOPE AND PURPOSE}

The purpose of this project was to evaluate the feasibility of acoustic emission ( $\mathrm{AE}$ ) as a method for recognizing and predicting in-process cutting tool failure. Areas of consideration are: 1) development of a demonstration experiment in which this technology is applied to a typical machining application at Allied Corporation, Bendix Kansas City Division (BKC)*; 2) determine the capabilities of $\mathrm{AE}$, to predict cutting tool failure and tool breakage detection based on tool size; 3) apply $A E$ to an existing test to determine its ability to detect turning insert wear. The objectives are primarily tailored toward the Monarch Cortland Vertical Milling Machines common to BKC production departments. If successful, $A E$ monitors could be installed on all Cortland Mills. This effort is applicable to all new machine tools purchased with monitors, including the proposed Flexible Machining System (FMS). AE could also be applied effectively on tests performed in the Process and Machining Evaluation Lab (PMEL).

\section{PRIOR WORK}

Previous studies dealing with Acoustic Emission applications are related to materials testing. This is the first study within the complex dealing with the application of determining tool breakage and predicting tool wear.

\section{ACTIVITY}

\section{Background}

Metallurgically, the machining process involves plastic deformation. The workpiece material undergoes severe plastic deformation in the shear plane which emanates from the cutting edge of the tool. This deformation occurs through several metallurgical processes including dislocation motion, twinning, grain boundary sliding, vacancy coalescence, crack nucleation, decohesion and fracture of inclusions. These processes produce both heat and stress waves and are transferred through the workpiece material into the cutting tool.

"Acoustic emission ( $A E$ ), is defined as the transient elastic energy spontaneously released in materials undergoing deformation fracture or both." 1 All metal machining processes, utilizing a cutting tool, are involved with concentrated shear deformation. The shear plane approaches the undeformed material. As the shear plane crosses the undeformed material, transient elastic energy is released and the above processes occur.

This report was originally published in 1987 . The current corporate name is AlliedSignal Inc., Federal Manufacturing \& Technologies. 
Different studies have used vibration signature, audio, and $A E$ analysis to monitor the machining process. Frequently, confusion exists between these methods. Audio emissions are caused by vibrations within the 15 to $20 \mathrm{kHz}$ range. Vibration signature analysis is performed on signals between $1 \mathrm{~Hz}$ and $100 \mathrm{kHz}$. Acoustic emissions, related to the plastic processes of machining, are within the range of $100 \mathrm{kHz}$ to $1 \mathrm{MHz}$. The $\mathrm{AE}$ signals are orders of magnitude smaller than the signal generated at the lower frequencies but are not as affected by noises generated by machine vibrations.

The metallurgical processes, previously described, produce the high frequency, low energy stress waves that travel throughout the workpiece material and the cutting tool. When these waves reach a boundary surface, the surface deforms. An AE transducer uses a piezo electric crystal as the sensing element. The transducer, which the user bonds to the surface being analyzed, produces voltage output proportional to the magnitude and at the same frequency as the stress wave. The stress waves travel through the material at the speed of sound (for steel, this speed is $5050 \mathrm{~m} / \mathrm{s}$ ).

The machining process produces these signals continuously. The quantity and magnitude vary within a range until something changes. For example, as a built up edge (BUE) breaks off, a burst of acoustic energy is released. $\mathrm{AE}$ bursts are also produced by chipping and break down of the cutting edge. As the cutting edge disintegrates, the amount of acoustic activity increases beyond the normal range.

Acoustic emissions are also produced by the chip rubbing against the face of a turning tool (rake surface on an end mill and the flute face on a drili). Emissions are produced as the chip changes direction after being sheared from the workpiece. As chips break apart, they also produce emissions. Finally, if the chips are continuous and wrap around the tool in a "birds nest" they produce additional emissions. The investigator must separate the different sources of the $\mathrm{AE}$ to detect and predict failure.

Today, investigators use selective filtering and classification algorithms to allow the artificial intelligence programmed into the monitors to discriminate between the different types of $\mathrm{AE}$ outputs.

Papers by Professor David A. Dornfeld, noted in the bibliography, present a step by step development (experimentally and theoretically) of acoustic emission as an in-process monitoring tool. Dornfeld addresses techniques to determine the types of chips produced in the turning process. Most papers in the bibliography are related to the turning process. In all cases, 
the AE transducer was mounted directly to the cutting tool or the tool holder. With this set-up, the application of theory to actual practice is very successful. Currently, Kennametal, Inc., sells a cutting tool monitor based on this technology.

The output of the $\mathrm{AE}$ transducer is a nonperiodic voltage containing many frequencies. The root mean square (rms) voltage of the raw AE signal is the preferred signal type for investigations. By taking the rms voltage the signal is smoothed out and less sensitive to small variations in electronic gain.

Dornfeld has presented a quantitative model of acoustic emission output for orthogonal cutting. The model is based on the premise that metal cutting is dependent upon the applied strain rate, flow stress of the metal being machined, and the volume of the material undergoing deformation in the cutting process. This allows the development of an equation that relates acoustic emission signal output (Vrms) to the machining variables. His equation is :

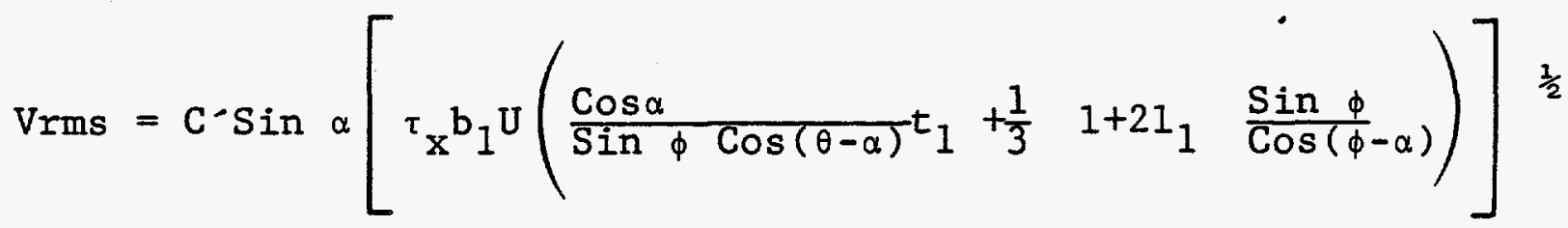

where: Vrms output voltage (root mean square)

$C^{\prime}$ proportionality constant based on test instrumentation

$\phi$ shear angle

a rake angle

$t_{1}$ chip thickness (uncut)

$\mathrm{U}^{1}$ cutting velocity

1 chip contact length

Tk workpiece shear strength

b width of cut

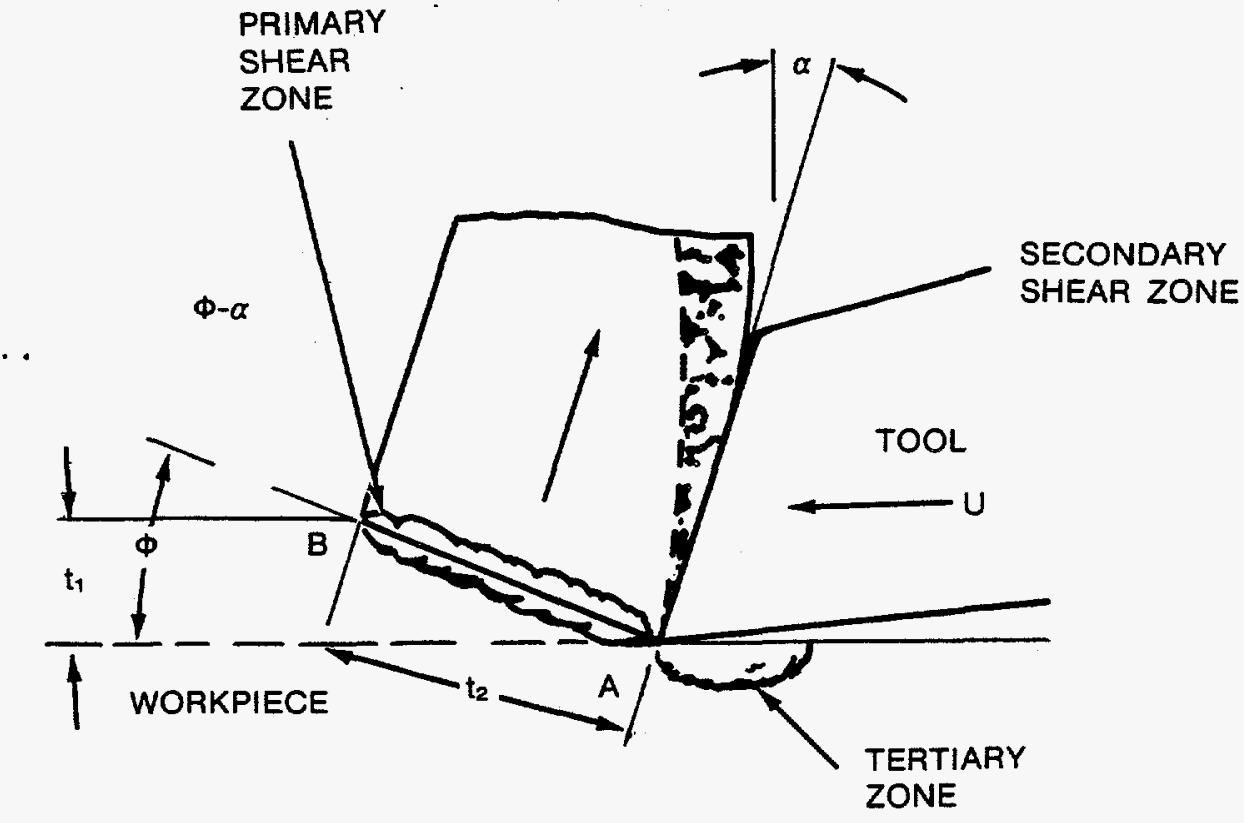




\section{Literature Search}

An initial search conducted through the Technical Information Center generated one reference. Additional sources of references and papers were obtained from the Physical Acoustics Corp. and Acoustic Emission Technology Corp. Using the vendor supplied references, most of the current papers concerned with cutting tool monitoring and wear detection were obtained. Papers on basic acoustic emission technology are noted in the bibliography.

Experimental Activity

Since little work had previously been performed on a machine tool where the tool rotates and the workpiece is stationary, a drilling experiment was developed on the Monarch Cortland CNC Mili. Thirty-two of these mills are currently located throughout the plant. In addition, a turning experiment currently being run in the PMEL was monitored.

Experimental Set-Up

Equipment and manpower expertise to support this study were supplied by Quality Engineering. The equipment included an Acoustic Emission Technology Corp. (Sacramento, CA) Mode1 204B/BR AE Test System (CE62063) and Dunegan Model S140B AE transducers. The $\mathrm{AE}$ system included a portable readout signal conditioning package and necessary transducer preamplifiers.

The AE transducers were mounted to the machine tool under study with a two-part Dura-Kore Dental Cement (Store 99014062 Powder, 99014064 Liquid) which is rigid and nonconductive when it cures. A Honeywel1 Model 1858 Visicorder with Model 1883 Amplifiers was connected directly to the $A E$ test system to obtain hard copies of the $\mathrm{AE}$ signals. Both the amplified output of the raw $\mathrm{AE}$ signals and the root mean square sum of the $\mathrm{AE}$ signal voltage (Vrms) were recorded.

Drill testing for a previous project Hard Coatings of High Speed Cutting Tools, had been performed on the Cortland Mill. Using similar cutting tools and specimens, the speeds and feeds developed previously were used for this test. In addition, drill life could be compared for the test.

A 13/64 (0.2031 in.) diameter dril1 had been selected for a hard coating study. This jobber length, high speed steel drill with a 118 degree standard point had been purchased from a twist drill manufacturer (manufacturer one) in a large quantity from a single production run. It is a commonly used drill and is the recommended size for drilling a 1/4-20UNC-2B tapped hole. In the size range between 0.201 and 0.204 in. there are 26 active standard drills which had a combined usage of 1540 pieces in 1985 . 
A similar drill was obtained (Tool No. 50120300) produced by a different manufacturer (manufacturer 2). This allowed the comparison of the effects of two different manufacturers on acoustic response and tool life. This drill is also a standard jobber length with a 118 degree general purpose point.

The hard coating team leader supplied titanium nitrite (TiN) coated drills used for their hard coating study. The drills were selected from the original lot purchased from manufacturer one and coated by the three main manufacturers of PVD (Physical Vapor Deposite) equipment. Four drills from each of the coated lots were supplied to the PMEL for this test.

High speed steel (HSS) drills were selected to maintain consistency in tool selection. Samples selected were:

A 3/32 ( 0.0938 in.), jobber length, 118 degree, standard point, HSS, drill (tool no. 50108900) and 3/32, C-2 carbide equivalent (50108929). 0.033 in. jobber length, 118 degree, standard point, HSS, drill (tool no. 50102410) and number 67 (0.032), C-2 carbide equivalent (50102499).

Plates ( 12 by 12 by 1 ) made from 4340 steel were selected as the workpiece material. They were heat treated to Rockwell C35-38 and both sides were ground. This size plate permitted the use of the thrust table developed for the hard coating drilling study. Comparison was made of the change in thrust load to acoustic output. The coolant selected was Jon-Cool Formula 800 (97022454), a water soluble cutting fluid mixed at a 20 to 1 ratio.

The criteria established for ending a test run was a broken or excessively noisy drill. Dimensional change was not selected. Hole diameter did not vary more than the allowable diameter tolerance per CTS 1454800 before failure by the established criteria.

The drilling study was made in five phases. Phase one determined the optimum location of the $\mathrm{AE}$ input transducers on the Cortland Mill. Phase two determined the ability of $\mathrm{AE}$ to predict and detect failure. Phase three determined the effectiveness of $\mathrm{AE}$ to predict and detect failure over a range of tool sizes and various cutting tool materials. Phase four applied Dornfeld's model outside the single point turning concept and used it as a guide to determine $\mathrm{AE}$ output as tool size was changed. Phase five applied $\mathrm{AE}$ monitoring to a test currently in work to determine its effectiveness as a laboratory tool. This work was related to the turning model. 
Phase One Transducer Location

Mounting of the transducer is critical to the success of the study. Ideally, a permanent connection of the transducer and black box is desirable in order to reduce damage to the transducer. The technique of using acoustic emission to detect tool wear is most successful when the shortest most continuous path is used between the cutting tool and the acoustic transducer. A11 $\mathrm{AE}$ monitors currently marketed are for turning and have the transducer mounted on the tool post or tool holder. Companies developing machine tools with cutting tool monitors, based on acoustic emission are designing in an acoustic path for the best response. In the case of the Monarch Cortland Mill there is a very complicated discontinuous path between the cutting tool and a place to mount an acoustic transducer on the milling head. Figure D-1, Appendix D shows this path. The acoustic wave has to travel through the tool and into the tool holder which is mounted in the spindle. The spindle rotates inside the quill on roller bearings. The quill is clamped through the quill guides to the head. When the transducer is mounted on the quill housing high frequency emission that had traveled through six interfaces was measured. When mounted on the milling head, the signal traveled through eight interfaces.

Losses in the acoustic signals are encountered every time the signal crosses an interface. Losses across an interface can vary from 0 to $6 \mathrm{Dbs}$ ( 50 percent). The magnitude of these losses depends on whether the interface is static (bolted, pressed) or dynamic (roller bearing, slip). The Cortland milling head has interfaces of both types. The Cortland is designed to vary the preload on the spindle bearings as the spindle speed is increased from the low to high speed. Therefore, the losses in the acoustic signal across the bearings is a variable that is spindle speed dependent. Losses of the acoustic signal could be determined if the spindle assembly was built in stages and measurements were made of the loss as each new interface is added.

Initially, an AE transducer was mounted to the $\mathrm{Z}$-axis resolver mounted on the end of the spindle. A second transducer was mounted at the bottom of the milling head housing near the quill. A third transducer was mounted on the thrust table that was being used as a mounting fixture for the test plates. Figure D-2 shows the locations of the $\mathrm{AE}$ transducers on the Cortland Mill.

AE outputs from the two locations on the machine side of the cutting tool indicated the following.

The transducer on the resolver mount was picking up over 40 percent of its signal from the spindle rotation (bearing noise) and an additional 15 percent of the signal from spindle movement. Final tool failure was sensed but no warning signal was received (Figure $D-3$ ). 
The transducer on the base of the milling head was even more insensitive to the machining process. The revolving spindle represented over 60 percent of the signal. Again, cutting tool failure was detected, but no warning signal was received before failure (Figure $D-4)$. During one run, the spindle was fully retracted into the milling head and this background signal doubled.

Discussions were held with $\mathrm{AE}$ transducer manufacturers to determine if a transducer was available that would rotate with the spindle and allow the use of slip rings to bring the signal out of the machine tool. Though it would be ideal to develop such a sensor slip ring combination, at the present time there is nothing available. This option was rejected because of the limited time and development costs for such a transducer.

The Cortland Mills have an adjustable height milling head. By combining the height of the milling head and the extension of the quill, various set-ups can be made when all cutting tools are set to the same length. This would add additional complexity in developing a system to predict cutting tool failure.

The multiple acoustic emission sources encountered on the machine tool were disguising the signals being sought. A third transducer was mounted on the thrust table (Figure D-5). A very high percentage of parts machined on Cortland mills have their own unique machining fixtures. An acoustic emission transducer could be incorporated into the design of these fixtures. The transducer could be located in a nonvulnerable position where it could be protected. Concern is evidently related to the ability of the AE transducers to withstand the environment of metal chips, coolants and changing temperatures. The $\mathrm{AE}$ transducer was coated with RTV to waterproof both it and its electrical connection. Initially, problems were encountered with the chips penetrating the RTV coating and grounding the transducer to the machine tool. A polypropelyene sample cup was placed over the transducer and coated with RTV. This shield proved rugged enough for the remainder of the tests. A clean high output signal from the transducer (Figure D-6) was recorded.

Another concern was the effective distance between the AE transducer and the location where the plate was being drilled. Additional runs were made drilling holes 2 to 10 in. away from the transducer (Figure D-7). The effect of distance could not be separated from the normal variation in the $\mathrm{AE}$ signal that was obtained from hole to hole. The data summaries for these tests are included in Appendix C.

Phase Two Failure Detection

The data show the trend of increasing acoustic output with the increased wear. The initial data were analyzed and the results 
were constructed into a simple algorithm to predict failure. The algorithm stated, failure occurred after the AE Vrms signal had doubled from its initial value and maintained this level for two consecutive drilling operations. This allowed for examination of the data while drilling and the capability to predict tool failure.

Phase Three Size and Material Effects

Quality Reporting and Statistical Services designed a screening test to evaluate the effects of cutting tool size, speed, feed rate, tool material and distance from the transducer. The plan and test data are 1isted in Appendices $B$ and $C$.

Decreasing the drill size permitted modeling of smaller parts typically manufactured in some of the Machining Departments. The effects of size could be easily determined because tool geometry, instrumentation, workpiece materials and speed ( $\mathrm{sm}$ ) were maintained. The design of the experiment also allowed evaluation of Dornfeld's equation on orthogonal cutting to other machining operations without having to determine the empirical constants.

During the tests, premature drill failure occurred at high feed and low speed conditions. An alternative feed rate was selected. The test sequence was then performed without premature drill failure. The revised feed rates are included in the test plan in Appendix A. One of the load cells in the thrust table failed during the runs on the coated drills and a spacer was installed to avoid delay of the test. No additional thrust data were obtained. Figures $D-4$ and $D-6$ show $A E$ was more sensitive than thrust load in its ability to predict drill failure.

Phase Four Application of AE Model to Drilling

Dornfeld's Quantitative Model for turning was related to the drilling data generated. By maintaining similitude, verification of the AE model could be made if the output changed by the same percentages as the theoretical. Simplifying assumptions were: 1) the chips are always in contact with the drill as they move up the flutes and 2) the geometries were similar. The influence of the second term of the equation would than have little effect. The angles in the equation would remain constant. Therefore, the equation was reduced to:

Vrms $=\{b 1 \mathrm{U} t 1\}^{\frac{1}{2}}$

The drilling data were evaluated with this equation. 


\section{Turning Tests}

After completing the drilling part of the investigation, an opportunity for applying $A E$ to determine the cause of another type of cutting tool failure was presented. Concurrently to this test, turning tests for another process development investigation were underway. The turning model tests experienced premature insert failure during lathe testing. The possibility of inclusions was suspected in the 304L Stainless Steel billet under test during a break in the testing sequence when the billets were changed, and the $\mathrm{AE}$ transducer was mounted to the top of the front turret of the American Hustler Lathe (Figure D-8) (C.E.51561, American Tool Co.; Cincinnati, Ohio). For the remaining twenty-two of the these forty-eight runs of this Statistical Screening Test, the AE output was recorded. This screening test was to evaluate first, second and third level interactions for thirty-six variables including lead angle, back rake angle, side rake angle, insert material, cutting speed, feed rate and depth of cut to the surface finish and cutting tool wear. The AE Vrms output was compiled with surface finish, tool wear, and chip thickness recorded. Appendix A includes an explanation of the test plan and the data sheets. In addition to using $\mathrm{AE}$ to determine the existence of hard spots in the billet, a determination of tool wear versus $A E$ response, in turning, could be made and a threshold value for tool wear established.

\section{$\underline{\text { Results }}$}

Drilling Study

$\mathrm{AE}$ was able to detect drill failure but was not always able to predict drill failure. The ability to predict drill failure was affected by both drill size and material. As drill size was reduced, the ability to predict failure was reduced. As drill size became smaller the effect of tool material was more pronounced in $\mathrm{AE}$ ability to predict failure. Titanium nitride coatings also affected the ability to predict failure.

The drilling study used several size drills made with different materials and coating configured as follows:

Size

0.203 in.

\section{Description}

Manufacturer One, High Speed Steel (HSS)

Manufacturer Two, HSS

Manufacturer One, TiN Coated, Vendor One Manufacturer One, TiN Coated, Vendor Two Manufacturer One, TiN Coated, Vendor Three 
0.093 in.

0.033 in.
HSS

C-2 Solid Carbide

HSS

C-2 Solid Carbide

0.203 in. Diameter Drills

Table 1 is a summary of the testing on the 0.203 in. diameter drills. The data summaries for all the drilling tests are included in Appendix A.

The drills coated by vendor one with titanium nitride produced very high $A E$ outputs on drilling the first hole. Successive holes showed lower AE levels that build back up as the drill approached failure. Based on the simple algorithm of predicting failure based on twice the initial output (or modified to twice the average of the first three holes) $\mathrm{AE}$ could not predict failure. Typically, the initial output was four times higher than the output on the second or third hole. One other drill coated by vendor three exhibited this behavior. This behavior is not indicative of the tool life. Some drills drilled a high number of holes $(104,61,32$ holes) while others failed immediately ( 1,3 holes). None of the uncoated or carbide drills used in this study exhibited this trait. This trait may be related to how the tool is prepared prior to coating. This trait was evident on drills received from two coating vendors. On the remaining drills, failure was predicted sixteen times. In two cases, the acoustic output had increased but not enough to predict failure.

The uncoated high speed steel (M-7) drills from manufacturer one and manufacturer two had different lives. The drills from manufacturer two had a 20 percent higher life at the high cutting speed than the drills from manufacturer one. Manufacturer one drills had a significantly higher life (150 percent) at the lower cutting speed. The drills from the two manufacturers had a 9 Rockwell points difference in hardness. AE was able to tell a difference between the drills coated by the different suppliers of coating equipment.

Caution is suggested in using acoustic emission as a wear predictor and failure monitor with titanium nitride coated tools when the possibility exists of high acoustic output on drilling the first hole. Ignoring the high output on the first hole, $\mathrm{AE}$ can be used effectively, to predict failure; but, the ability to detect failure on the first hole is lost. One of the TiN coated drills failed drilling the first hole.

0.093 in. Diameter Drills

Table 2 is the summary for the 0.093 in. diameter drill tests. $\mathrm{AE}$ was able to predict failure in all cases. It was easier to 
Table 1. Acoustic Emission Dril1 Study 0.203 in. Diameter Dril1

\begin{tabular}{|c|c|c|c|c|c|c|c|c|c|c|c|c|c|}
\hline \multirow{2}{*}{$\begin{array}{l}\text { Speed } \\
\text { RPM }\end{array}$} & \multirow[b]{2}{*}{ SFM } & \multirow{2}{*}{$\begin{array}{l}\text { Feed } \\
\text { in/min }\end{array}$} & \multirow[b]{2}{*}{$\begin{array}{l}\text { In/Rev } \\
\times 10-3\end{array}$} & \multicolumn{2}{|c|}{ Manufacturer 1} & \multicolumn{2}{|c|}{ Manufacturer 2} & \multirow{2}{*}{$\begin{array}{l}\text { Coating } \\
\text { \# Holes } \\
\text { Fallure }\end{array}$} & \multirow{2}{*}{$\begin{array}{c}\text { Vendor } 1 \\
\text { Pred. } \\
\text { Failure }\end{array}$} & \multirow{2}{*}{$\begin{array}{l}\text { Coating } \\
\text { * Holes } \\
\text { Failure }\end{array}$} & \multirow{2}{*}{$\begin{array}{l}\text { Vendor } 2 \\
\text { Pred. } \\
\text { Failure }\end{array}$} & \multirow{2}{*}{$\begin{array}{l}\text { Coating } \\
\text { \# Holes } \\
\text { Failure }\end{array}$} & \multirow{2}{*}{$\begin{array}{c}\text { Vendor } 3 \\
\text { Pred. } \\
\text { Fallure }\end{array}$} \\
\hline & & & & $\begin{array}{l}\text { \# Holes } \\
\text { Failure }\end{array}$ & $\begin{array}{l}\text { Pred. } \\
\text { Fallure }\end{array}$ & $\begin{array}{l}\text { \# Holes } \\
\text { Failure }\end{array}$ & $\begin{array}{l}\text { Pred. } \\
\text { Failure }\end{array}$ & & & & & & \\
\hline $1,653.00$ & 87.00 & 2.80 & 1.69 & 27.00 & 2.00 & 36.00 & 3.00 & 104.00 & None & 15.00 & 1.00 & 8.00 & 1.00 \\
\hline $1,653.00$ & 87.00 & 3.30 & 2.00 & $\begin{array}{l}23.00 \\
(2)\end{array}$ & 2.00 & $\begin{array}{l}27.00 \\
(3)\end{array}$ & 2.00 & 20.00 & None & 66.00 & 5.00 & 35.00 & 3.00 \\
\hline 684.00 & 36.40 & 2.80 & 4.09 & 123.00 & 2.00 & 67.00 & 1.00 & 3.00 & None & 199.00 & 4.00 & 61.00 & None (1) \\
\hline 684.00 & 36.40 & 3.30 & 4.82 & $\begin{array}{c}252.00 \\
(4)\end{array}$ & & 84.00 & No & 1.00 & None & 75.00 & Increase & 6.00 & No \\
\hline
\end{tabular}

(1) If 1st hole omitted could predict fallure by 6 holes

(2) Average of 3 drills

(3) Average of 7 drills

(4) Test stopped. No drill failure. 
Table 2. Acoustic Emission Drill Study 0.093 in. Diameter Drill

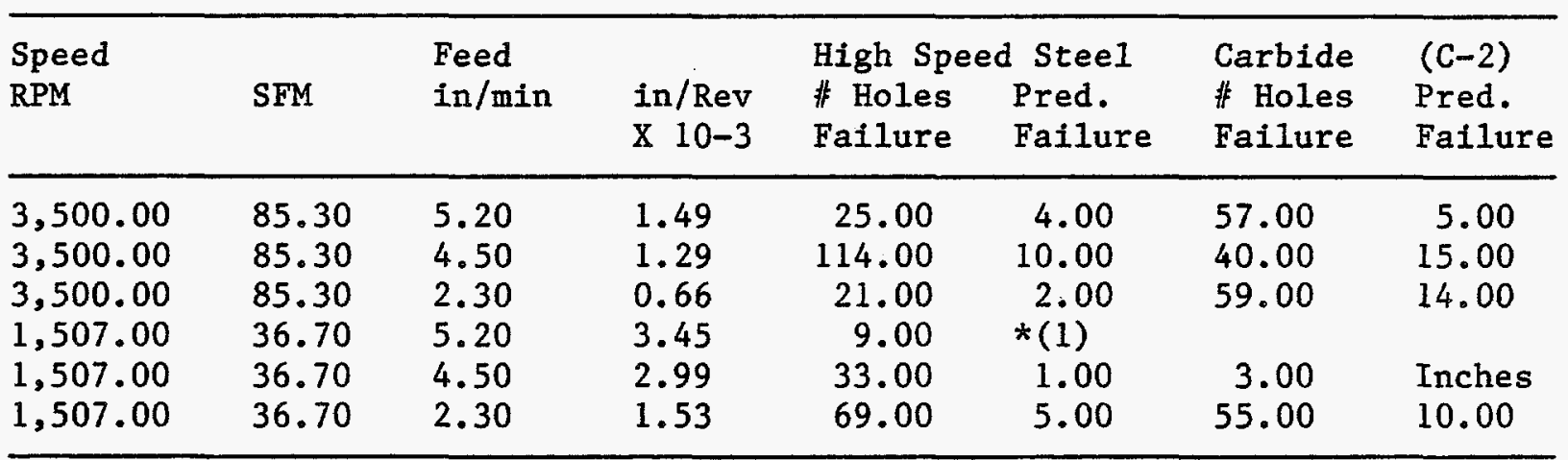

* 1 Drill flexing and did not complete run.

predict failure with drills made from carbide versus high speed steel. The carbide drills are both harder and stronger and produce a higher output. The carbide drills will not deflect and absorb energy.

0.033 in. Diameter Drills

Table 3 is the result summary for the 0.033 in. diameter drills tested. When testing these drills amplifier gains as high as $76 \mathrm{Dbs}(\mathrm{X} 10,000)$ were used. At this level AE could pick up the background emissions of the machine tool. At $80 \mathrm{Db}$ gain AE could detect the effects of coolant flow on the workpiece. $A E$ was able to predict failure for 80 percent of the carbide drills. AE was not as successful with the high speed steel drill being able to predict failure in only 40 percent of the cases.

Model Correlation

The change in magnitude of the drilling data was related to the change in magnitude of the simplified quantitative model. The following was found:

$\begin{array}{llll}\begin{array}{l}\text { Diameter Change } \\ \text { (in.) }\end{array} & \begin{array}{l}\text { Experimental } \\ \text { (percent) }\end{array} & \begin{array}{l}\text { Theoretical } \\ \text { (percent) }\end{array} & \begin{array}{l}\text { Difference } \\ \text { (percent) }\end{array} \\ 0.206 \text { to } 0.093 & 31.6 & 54.6 & 57.3 \\ 0.206 \text { to } 0.033 & 12.6 & 20.1 & 62.0\end{array}$

Although the test data are not in complete agreement with the theoretical calculation, the amount of error remained constant. The theoretical values were higher than the experimental. The effect of the chisel point and the corner of the cutting edge do 
Table 3. Acoustic Emission Drill Study 0.033 in. Diameter Drill

\begin{tabular}{|c|c|c|c|c|c|c|c|}
\hline $\begin{array}{l}\text { Speed } \\
\text { RPM }\end{array}$ & SFM & $\begin{array}{l}\text { Feed } \\
\text { in/min }\end{array}$ & $\begin{array}{l}\text { in/Rev } \\
\times 10-3\end{array}$ & $\begin{array}{l}\text { High Speed } \\
\text { \# Holes } \\
\text { Failure }\end{array}$ & $\begin{array}{l}\text { Steel } \\
\text { Pred. } \\
\text { Failure }\end{array}$ & $\begin{array}{l}\text { Carbide } \\
\text { \# Holes } \\
\text { Failure }\end{array}$ & $\begin{array}{l}\text { ( } \mathrm{C}-2) \\
\text { Pred. } \\
\text { Failure }\end{array}$ \\
\hline $\begin{array}{l}9,042.00 \\
9,042.00 \\
9,042.00 \\
6,366.00 \\
6,366.00\end{array}$ & $\begin{array}{l}78.17 \\
78.17 \\
78.17 \\
55.04 \\
55.04\end{array}$ & $\begin{array}{l}2.40 \\
6.80 \\
5.70 \\
5.70 \\
2.40\end{array}$ & $\begin{array}{l}0.27 \\
0.75 \\
0.63 \\
0.90 \\
0.38\end{array}$ & $\begin{array}{l}14.00 \\
15.00 \\
26.00 \\
21.00 \\
21.00\end{array}$ & $\begin{array}{l}2.00 \\
*(1) \\
10.00 \\
\text { No } \\
1.00\end{array}$ & $\begin{array}{r}75.00 \\
102.00 \\
103.00 \\
47.00 \\
88.00\end{array}$ & $\begin{array}{r}20.00 \\
9.00 \\
3.00 \\
\text { No } \\
2.00\end{array}$ \\
\hline
\end{tabular}

*1 Drill flexing, did not complete run.

have an effect on the results. More work needs to be done to develop a modified model for other machining operations.

Turning Test

All test data appear in Appendix C. The stainless steel billet with the hard spot was replaced before $\mathrm{AE}$ monitoring of the turning process was started. The turning process produces a higher magnitude signal than the drilling process. Indexing the square front turret had no noticeable effect on the emissions of the turning process. During the twenty-two runs that the $\mathrm{AE}$ output was monitored, only one failure was detected. Of the remaining twenty-one runs only five runs had insert wear greater than 0.007 in. as measured by the IMOG procedure. In al1 cases the $\mathrm{AE}$ output had started to increase. The turning tests were time controlled. If the tests had run longer, $\mathrm{AE}$ might have been able to predict insert failure. The Machinability Data Center notes for their Practical Machining Principles for Shop Application Seminar state their end point for tool life testing of carbide turning tool is flank wear of 0.015 in. Based on this criteria, none of the inserts had failed because of wear. Certain BKC applications in-plant do not allow 0.015 in. wear on an insert. Of the two inserts that had worn at least 0.010 in., the $A E$ output had increased and was being observed for failure.

\section{ACCOMPLISHMENTS}

\section{Drilling Study}

In all tool sizes and tool materials the following conclusions were drawn: 
AE could always detect drill failure.

* The more rigid the tool (larger) and stronger the tool (higher modulus of elasticity and strength) the higher the $\mathrm{AE}$ output and the better the ability to predict failure.

As the limit of the detection capability is approached, all factors have influence in the ability of $\mathrm{AE}$ to detect and predict failure.

$*$

$\mathrm{AE}$ always predicted failure before it could be predicted by monitoring thrust load. The change in outputs was always higher.

* Higher cutting speeds produced higher AE output. Cutting speeds had more of an effect on $A E$ output than fed rates.

\section{Turning Study}

The following conclusions can be made from the turning test:

* There must be a sufficient wear of the insert in order to predict failure with $\mathrm{AE}$.

* High cutting speeds produced higher AE output.

* The effect of cutting speed on AE output was greater than increased feed rate.

FUTURE WORK

AE technology presents an opportunity to develop a technique to predict cutting tool failure. This technology can be applied to CNC Milling Centers when the $\mathrm{AE}$ transducer is incorporated into the design of the holding fixtures. BKC can use this technology with small size drills. AE can be used to monitor tool wear and failure; but, one must be careful with its application. Monitoring equipment amplifier gains and failure algorithms will be different for each tool in a machining set-up. The $A E$ equipment gain will be fed into a microprocessor controlled monitor with memory capability for each set-up. When different tool materials or geometries are changed, the algorithms will have to be changed. The monitor must have the capability to compare $\mathrm{AE}$ outputs from part-to-part and be integrated into the CNC machine tool control so it can be properly sequenced with the $\mathrm{NC}$ program. Variability in materials will have an effect on $\mathrm{AE}$ outputs. With the development of artificial intelligence, sophisticated algorithms, and selective filtering, the ability to discriminate between the different sources of acoustic emissions will improve the ability to predict cutting tool failure. Additional investigative work is justified. 
The equipment that was used for this investigation was adequate for this feasibility study. Future work will require equipment with selective filtering capabilities and computer compatibility for real-time analysis of the AE output signals. This would allow the application of artificial intelligence. 


\section{REFERENCE}

1 J. C. Spanner, "Acoustic Emission Applications and Trends," Elastic Waves and Nondestructive Testing of Materials, ASME, Volume 24, 1978 . 


\section{BIBLIOGRAPHY}

Arrington, M. Acoustic Emission - An Introduction for Engineers.

Balderston, H. I. "The Broad Range Detection of Incipient Failure Using the AE Phenomena," STP 505; ASTM, Symposium of ASTM Acoustic Emission, pp 297-317, December 1971 .

Baur, Paul. Detecting Incipient Failure by Monitoring Acoustic Emission Power, pp 67-73, December 1982.

Dornfeld, D. A. and Pan, Chung-Shih. "A Study of Continuous/ Discontinuous Chip Formation Using Acoustic Emission," Journal of Applied Metalworking, Volume 4, Number 1, pp 18-29, July 1985.

Dornfeld, D. A. "Investigation of Machining, \& Cutting Tool Wear \& Chatter Using Acoustic Emission," Proceedings AF/DARPA Review of Progress in Quantitative NDE, Univ. of Col., pp 1-9, August 1981.

Dornfeld, D. A. and Lan, M. S. "Chip Form Detection Using Acoustic Emission," Proc. 11 NAMRC, Univ. of Wisconsin at Madison SME, pp 386-389, May 1983.

Dornfeld, D. A. "Monitoring for Untended Manufacturing Using Acoustic Emission," STCE Conf. Advances in Tool Material for Use in HS Machining, February 1987.

Dornfeld, David A. "An Investigation of Orthogonal Cutting via Acoustic Emission Signal Analysis," Proc. 7th NAMWRC, SME at University of Michigan, pp 270-274.

Dornfeld, David A. "Acoustic Emis. and Metalworking-Survey of Potential and Examples of Applications," Proc. 8th NAMRC at University of Missouri at Rolla, pp 270-274, May 1980.

Finley, R. W. "Incipient Failure Detection in Rotating Machinery," Chemical Engineering, pp 104-112, July 1985.

Gillis, Peter P. and Hamstad, Marvin A. "Some Fundamental Aspects of the Theory of Acoustic Emission," Material Science and Engineering, Volume 14, pp 103-108, January 1974 .

Grabec, I. and Leskovar, P. "Acoustic Emission of a Cutting Process," Ultrasonics, Volume 15, Number 1, pp 17-20, January 1977 . 
Hamsted, M. A. "On Energy Measurement of Continuous Acoustic Emission," UCRL Rep. 76286 Lawrence Livermore National Lab, December 1974.

Hi11, R. and Stephens, R. W. "Simple Theory of Acoustic Emission-Consideration of Measurement Parameters," Acoustica, Volume 31, Number 4, pp 224-230, April 1974.

Hsu, N. N. and Hardy, S. C. "Experiments in Acoustic Emission Waveform Analysis for Characterization of AE Elastic Waves \& Non-Destructive Testing of Materials," Winter Annual Meeting of ASME, pp 85-106, December 1978.

Hutton, P. H. "Acoustic Emission Applied Outside of the Laboratory," STP 505; ASTM, Symposium of ASTM Acoustic Emission, pp 114-128, December 1971.

Iwata, K. and Moriwaki, T. "Application of Acoustic Emission Measurements to In-Process Sensing of Tool Wear," Annals of the CIRP, Volume 25, Number 1, pp 21-26, January 1977 .

Kakino, Yoshiaki. "In-Process Detection of Too1 Breakage by Monitoring Acoustic Emission Cutting Tool Materials," Proceedings of International Conf. ASM \& SME, September 1980 .

Kaneeda, T. and Tsuwa, H. "Detecting Fracture Phenomena in Separation Process at Tool Tip in Metal Cutting," Journal of Japan Society of Precision Engineering, Volume 13, Number 3, pp 159-160, October 1979.

Kannatey-Asibu, E. and Dornfeld, D. A. "A Study of Tool Wear Using Statistical Analysis of Metal Cutting Acoustic Emission," Wear, Volume 76, Number 2, pp 247-262, February $19 \overline{82}$.

Kannatey-Asibu, E. and Dornfeld, D. A. "Quantitative Relationship for Acoustic Emission from Orthogonal Metal Cutting," Transactions of the ASME, Volume 10, Number 3 , pp 330-340, August 1981 .

Kannatey-Asibu, E. and Dornfeld, D. A. "Acoustic Emission During Orthogonal Metal Cutting, "International Journal of Mechanical Science, Volume 22, Number 5, pp 285-296, July 1980 .

Kim, K. J. and Kim, K. H. Progressive Tool Wear Sensing in Turning Operations via AE Signal Processing, pp 291-307. 
Lan, M. S. and Dornfeld, D. A. "Experimental Studies of Tool Wear via Acoustic Emission Analysis," Proc. 10th NAMRC, McMaster Univ., Hamilton, Ontario, pp 305-311, SME, May 1982.

Micheletti, G. F. and Koenig, W. "In Process Tool Wear Sensor for Cutting Operations," Annals of the CIRP, Volume 25, Number 2, pp 396-483, July 1976.

Moriwaki, T. "Detection for Cutting Tool Fracture by Acoustic Emission Measurements," Annals of the CIRP, Volume 29, Number 1, pp 35-40, January 1980 .

Rao, A. K. and Murthy, C. R. "Analysis of Acoustic Emission: A View, and Advances in Fracture Research (Fracture 84)," Proc. of 6th International Conf. on Fracture (ICF6), Volume 1, pp 669-689, December 1984.

Schaffer, George. "The Eyes and Ears of CIM," American Machinist, Volume 127, Number 7, pP 109-124, July 1983.

Uehara, Kunid, and Kanda, Yuichi. "Identification of Chip Formation Mechanism through Acoustic Emission Measurement," Annals of the CIRP, Volume 33 , Number 1, PP 71-74, January 1984 .

Vahaviolos, S. J. "Application of Acoustic Emission to Factory Automation and Process Control," Material Evaluation, Volume 42, pp 1650-1655, December 1984.

Weller, E. J. and Schrier, H. M. "What Sound Can Be Expected From a Worn Tool," Transactions of ASME, Volume 91, Number 3, pp 525-534, January 1969 . 
Appendix A

TEST PLAN 
Test Plan:

The test plan developed by the Statistical Group, D/462, is based on a fractional factorial experiment. Factors that were evaluated were drill size, cutting speed, feed rate, tool material, and distance from the transducer. Tool point geometry was held constant.

The test plate was split into two areas, the near and far sections. Odd number holes were always in the near section, even in the far section. Hole drilling was always done in pairs (odd, even), alternating between the near and far section. The holes were always six inches apart.

The experimental layout was as follows:

\begin{tabular}{|c|c|c|}
\hline & $\begin{array}{l}\text { High } \\
\text { Leve1 }\end{array}$ & $\begin{array}{l}\text { Low } \\
\text { Leve1 }\end{array}$ \\
\hline $\begin{array}{l}\text { Distance from Sensor } \\
\text { Cutting Speed } \\
\text { Feed Rate } \\
\text { Drill Material/Coating }\end{array}$ & $\begin{array}{l}\text { D2 } \\
\text { S2 } \\
\text { F2 } \\
\text { M2 }\end{array}$ & $\begin{array}{l}\text { D1 } \\
\text { S1 } \\
\text { F1 } \\
\text { M1 }\end{array}$ \\
\hline $\begin{array}{l}\text { Test } \\
\text { Condition }\end{array}$ & $\begin{array}{c}.033 / .093 / .203 \\
\text { Diameter }\end{array}$ & \\
\hline $\begin{array}{l}1 \\
2 \\
3 \\
4 \\
5 \\
6 \\
7 \\
8\end{array}$ & $\begin{array}{l}\mathrm{D} 1 / \mathrm{D} 2(\mathrm{~S} 2, \mathrm{~F} 1, \mathrm{M} 1) \\
\mathrm{D} 1 / \mathrm{D} 2(\mathrm{~S} 1, \mathrm{~F} 2, \mathrm{M} 2) \\
\mathrm{D} 1 / \mathrm{D} 2(\mathrm{~S} 1, \mathrm{~F} 2, \mathrm{M} 1) \\
\mathrm{D} 1 / \mathrm{D} 2(\mathrm{~S} 2, \mathrm{~F} 1, \mathrm{M} 2) \\
\mathrm{D} 1 / \mathrm{D} 2(\mathrm{~S} 1, \mathrm{~F} 1, \mathrm{M} 2) \\
\mathrm{D} 1 / \mathrm{D} 2(\mathrm{~S} 2, \mathrm{~F} 2, \mathrm{M} 1) \\
\mathrm{D} 1 / \mathrm{D} 2(\mathrm{~S} 1, \mathrm{~F} 1, \mathrm{M} 1) \\
\mathrm{D} 1 / \mathrm{D} 2(\mathrm{~S} 2, \mathrm{~F} 2, \mathrm{M} 2)\end{array}$ & \\
\hline
\end{tabular}

The Ml material was always a High Speed Steel jobber length drill. The cutting speeds and feed rate selected for the different size drills are listed below. Early failure of the smaller size drills was encountered at the high feed rate low cutting speed test condition. In these cases a second higher feed rate was selected and the test sequence rerun.

\begin{tabular}{lllll} 
& & \multicolumn{3}{c}{ Drill Size } \\
& & \multicolumn{1}{c}{.203} & \multicolumn{1}{c}{.093} & \multicolumn{1}{c}{.033} \\
S2 & Speed (RPM)/(SFM) & $1653 / 88$ & $3500 / 86$ & $9042 / 78$ \\
F2 & Feed Rate (In/Min)/(In/Rev) & $3.3 / .0020$ & $5.2 / .0015$ & $6.8 / 0008$ \\
S1 & Speed (RPM)/(SFM) & $684 / 34$ & $1507 / 37$ & $6366 / 55$ \\
F1 & Feed Rate (In/Min)/(In/Rev) & $2.8 / .0040$ & $2.3 / .0015$ & $2.4 / 0004$ \\
F1A & Feed Rate (In/Min)/(In/Rev) & -- & $4.5 / .0030$ & $5.7 / 0009$
\end{tabular}


Appendix B

ACOUSTIC EMISSION SCREENING TEST DATA 
Table B-1. Acoustic Emission Statistical Screening Test

0.203 in. Diameter Drills Both Coated and Uncoated

\begin{tabular}{|c|c|c|c|c|c|c|c|c|c|c|c|c|c|c|c|c|c|c|}
\hline Drill No. & $\begin{array}{l}\text { Speed } \\
\text { (RPM) }\end{array}$ & \multirow{2}{*}{$\begin{array}{l}\text { Feed } \\
(\ln / \min )\end{array}$} & \multirow{2}{*}{$\begin{array}{l}\text { Gain } \\
\text { (Db) }\end{array}$} & \multirow{2}{*}{\multicolumn{2}{|c|}{$\begin{array}{l}\text { No. of Hole } \\
\text { to Eallure }\end{array}$}} & \multicolumn{2}{|c|}{ Hole Nunbers } & \multirow{2}{*}{10.00} & \multirow{2}{*}{25.00} & \multirow{2}{*}{20.00} & \multirow{2}{*}{25.00} & \multirow{2}{*}{30.00} & \multirow{2}{*}{35.00} & \multirow{2}{*}{40.00} & \multirow{2}{*}{45.00} & \multirow{2}{*}{50.00} & \multirow{2}{*}{55.00} & \multirow{2}{*}{60.00} \\
\hline & & & & & & 1.00 & & & & & & & & & & & & \\
\hline D-21 & 1.653 .00 & 2.80 & 500 & & & 1.0 & & 7.00 & 8,00 & & & & & & & & & \\
\hline$D-46$ & $1,653.00$ & 3.30 & 50.00 & 79,00 & & 0.50 & 0.80 & 0.75 & 0.85 & 0.65 & 0.90 & 0.80 & 0.90 & 0.85 & 1.00 & 1.10 & 0.95 & 1.00 \\
\hline & & & & & & ole depth & set at & in. in & tead of. & 1n. Drill & failed $\mathrm{a}$ & c 35 equi & valent ho & les. & & & & \\
\hline$D-2$ & 684.00 & 2.80 & 50.00 & 61.00 & & 6.00 & 1.60 & 1.20 & 1.35 & 1.80 & 1.30 & 1.40 & 1.35 & 1.35 & 1.15 & 1.50 & 3.30 & 1.40 \\
\hline$D-5$ & 684.00 & 3,30 & 50,00 & 6.00 & & 1.10 & 180 & 6.00 & & & & & & & & & & \\
\hline & & & & & & & & & & & & 26.00 & 27.00 & 28.00 & 29.00 & & & \\
\hline c-16 & 684.00 & 3.30 & 50.00 & 29.00 & & 0.75 & 1.00 & 1.50 & 1.70 & 0.90 & 1.05 & 1.70 & 1.60 & 3.50 & 8.00 & & & \\
\hline & & & & & & & & & 14,00 & 15.00 & & & & & & & & \\
\hline$c-7$ & $1,653.00$ & 2.80 & 50.00 & 15.00 & & 3.00 & 0.80 & 1.15 & 5.20 & 7.00 & & & & & & & & \\
\hline$c-12$ & $1,653.00$ & 3.30 & 50.00 & 107.00 & & 0.30 & 0.40 & 0.45 & 0.50 & 0.60 & 0.65 & 0.55 & 0.90 & 0.85 & 0.85 & 0.80 & 0.70 & 0.95 \\
\hline & & & & & & & & & & & & & & & & & & \\
\hline$c-44$ & 084.00 & 2.80 & 50,00 & 199.00 & & 0.70 & 0.70 & 0.90 & 0.90 & 0.80 & 0.90 & 0.95 & 0.90 & 0.85 & 0.80 & 1.00 & 0.95 & 0.90 \\
\hline & & & & & & & 2.00 & 3.00 & & & & & & & & & & \\
\hline$B-8$ & 084.00 & 2.80 & 50.00 & 3.00 & & 5.00 & 5.40 & 7.80 & & & & & & & & & & \\
\hline$B-20$ & 684.00 & 3.30 & 50.00 & 1.00 & & 8.00 & & & & & & & & & & & & \\
\hline$B=6$ & $1,653.00$ & 2.80 & 50.00 & 104.00 & - & 6.80 & 1.20 & 1.20 & 2.90 & 1.80 & 1.50 & 2.50 & 2.30 & 1.80 & 1.80 & 1.40 & 0.85 & 0.90 \\
\hline B-48 & $1,653.00$ & 3.30 & 50.00 & 20.00 & & 2.20 & 5.80 & 1.40 & 1.70 & 8.00 & & & & & & & & \\
\hline NYTD-1 & 684.00 & 2.80 & 50.00 & 67.00 & & 1.10 & 1.60 & 1.40 & 1.40 & 1.20 & 1.20 & 1.25 & 1.30 & 1.20 & 1.45 & 1.05 & 1.20 & 1.20 \\
\hline
\end{tabular}


Table B-1, Continued. Acoustic Emission Statistical Screening Test

0.203 in. Diameter Drills Both Coated and Uncosted

\begin{tabular}{|c|c|c|c|c|c|c|c|c|c|c|c|c|c|c|c|c|c|c|}
\hline Dri11 No, & $\begin{array}{l}\text { Speed } \\
\text { (RPH) }\end{array}$ & $\begin{array}{l}\text { Feed } \\
(\text { In/mn })\end{array}$ & $\begin{array}{l}\text { Gain } \\
\text { (Db) }\end{array}$ & $\begin{array}{l}\text { No. of Hole } \\
\text { to Faillure }\end{array}$ & $\begin{array}{l}\text { Hole } \mathrm{N} \\
65.00\end{array}$ & $\begin{array}{l}\text { ers } \\
70.00\end{array}$ & 75,00 & 80.00 & 85.00 & 90.00 & 95.00 & 100.00 & 105.00 & 110.00 & & 190.00 & 200.00 & \\
\hline$D-21$ & $1,653.00$ & 2.80 & 50.00 & 8.00 & & & & & & & & & & & & & & \\
\hline D046 & $1,653.00$ & 3.30 & 50.00 & 79.00 & 1.05 & 1.20 & 1.65 & $\begin{array}{r}76.00 \\
3.15\end{array}$ & $\begin{array}{r}77.00 \\
4.65\end{array}$ & $\begin{array}{r}78.00 \\
8.00\end{array}$ & & & & & & & & \\
\hline D-2 & 684.00 & 2.80 & 50.00 & 61.00 & $\begin{array}{r}61.00 \\
8.00\end{array}$ & & & & & & & & & & & & & \\
\hline D-5 & 684.00 & 3.30 & 50.00 & 6.00 & & & & & & & & & & & & & & \\
\hline$c-16$ & 684.00 & 3.30 & 50.00 & 29.00 & & & & & & & & & & & & & & \\
\hline c-7 & $1,653.00$ & 2.80 & 50.00 & 15.00 & & & & & & & & & & & & & & \\
\hline c-12 & $1,653.00$ & 3.30 & 50.00 & 107.00 & 0.80 & 0.65 & 3.20 & 1.40 & 1.30 & 1.35 & 1.40 & 1.10 & $\begin{array}{r}104.00 \\
2.50\end{array}$ & $\begin{array}{r}105.00 \\
1.50\end{array}$ & $\begin{array}{r}106.00 \\
2.20\end{array}$ & $\begin{array}{r}107.00 \\
6.00\end{array}$ & & \\
\hline$c-44$ & 684.00 & 2.80 & 50.00 & 199.00 & 1.00 & 0.90 & 1.00 & 0.95 & 0.90 & 0.95 & 0.90 & 0.90 & 0.85 & $\begin{array}{r}195.00 \\
1.20\end{array}$ & $\begin{array}{r}196.00 \\
1.10\end{array}$ & $\begin{array}{r}197.00 \\
5.10\end{array}$ & $\begin{array}{r}198.00 \\
2.00\end{array}$ & $\begin{array}{r}199.00 \\
7.50\end{array}$ \\
\hline$B-8$ & 684.00 & 2.80 & 50.00 & 3.00 & & & & & & & & & & & & & & \\
\hline B-20 & 684.00 & 3.30 & 50.00 & 1.00 & & & & & & & & & & & & & & \\
\hline B-6 & $1,053.00$ & 2.80 & 50.00 & 104.00 & 0.95 & 0.85 & 0.85 & 0.95 & 1.00 & 0.70 & 0.85 & 0.70 & $\begin{array}{r}103.00 \\
1.30\end{array}$ & $\begin{array}{r}104.00 \\
8.00\end{array}$ & & & & \\
\hline B-48 & $1,653.00$ & 3.30 & 50.00 & 20.00 & & & & & & & & & & & & & & \\
\hline NYID -1 & 684.00 & 2.80 & 50.00 & 67.00 & 1.60 & $\begin{array}{r}66.00 \\
2.00\end{array}$ & $\begin{array}{r}67.00 \\
7.50\end{array}$ & & & & & & & & & & & \\
\hline
\end{tabular}


Table B-1, Continued. Acoustic Emission Statistical Screening Test

0.203 in. Diameter Drills Both Coated and Uncoated

\begin{tabular}{|c|c|c|c|c|c|c|c|c|c|c|c|c|c|c|c|c|}
\hline Drill No. & $\begin{array}{l}\text { Speed } \\
\text { (RPM) }\end{array}$ & $\begin{array}{l}\text { Peed } \\
\text { (In/min) }\end{array}$ & $\begin{array}{l}\text { Galn } \\
\text { (Db) }\end{array}$ & $\begin{array}{l}\text { No. of Hole } \\
\text { to Pallure }\end{array}$ & $\begin{array}{l}\text { Hole } \mathrm{N} \\
65.00\end{array}$ & $\begin{array}{l}\text { bers } \\
70.00\end{array}$ & 75.00 & 80.00 & 85.00 & 90.00 & 95.00 & 100.00 & 105.00 & 110.00 & 190.00 & 200.00 \\
\hline NYID-2 & 684.00 & 3.30 & 50.00 & 84.00 & 1.50 & 1.20 & 1.70 & 1.30 & $\begin{array}{r}82.00 \\
1.70\end{array}$ & $\begin{array}{r}83,00 \\
2.10\end{array}$ & $\begin{array}{r}84.00 \\
8.00\end{array}$ & & & & & \\
\hline NYrD-3 & $1,653.00$ & 3.30 & 50.00 & 24.00 & & & & & & & & & & & & \\
\hline mon-4 & $1,653.00$ & 2.80 & 50,00 & 35.00 & & & & & & & & & & & & \\
\hline NYrD-5 & $1,653.00$ & 3.30 & 50.00 & 34.00 & & & & & & & & & & & & \\
\hline
\end{tabular}


Table B-2. Acoustic Emission Preliminary Runs

0.203 in. Diameter Uncoated High Speed Steel Drills

Determination of Transducer Location

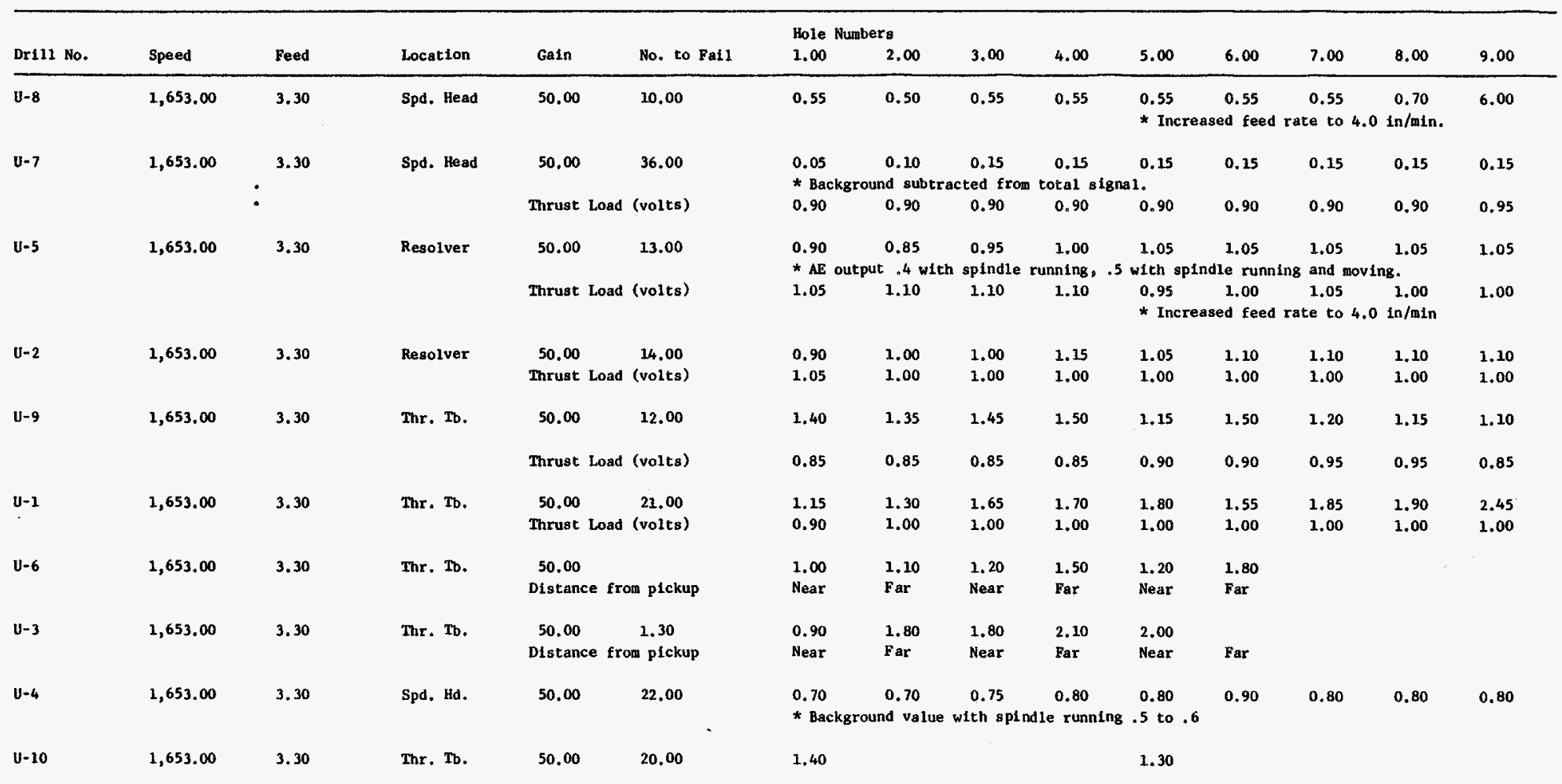


Table B-2, Continued. Acoustic Emission Preliminary Runs

0.203 in. Diameter Uncoated High Speed Steel Drills

Determination of Transducer Location

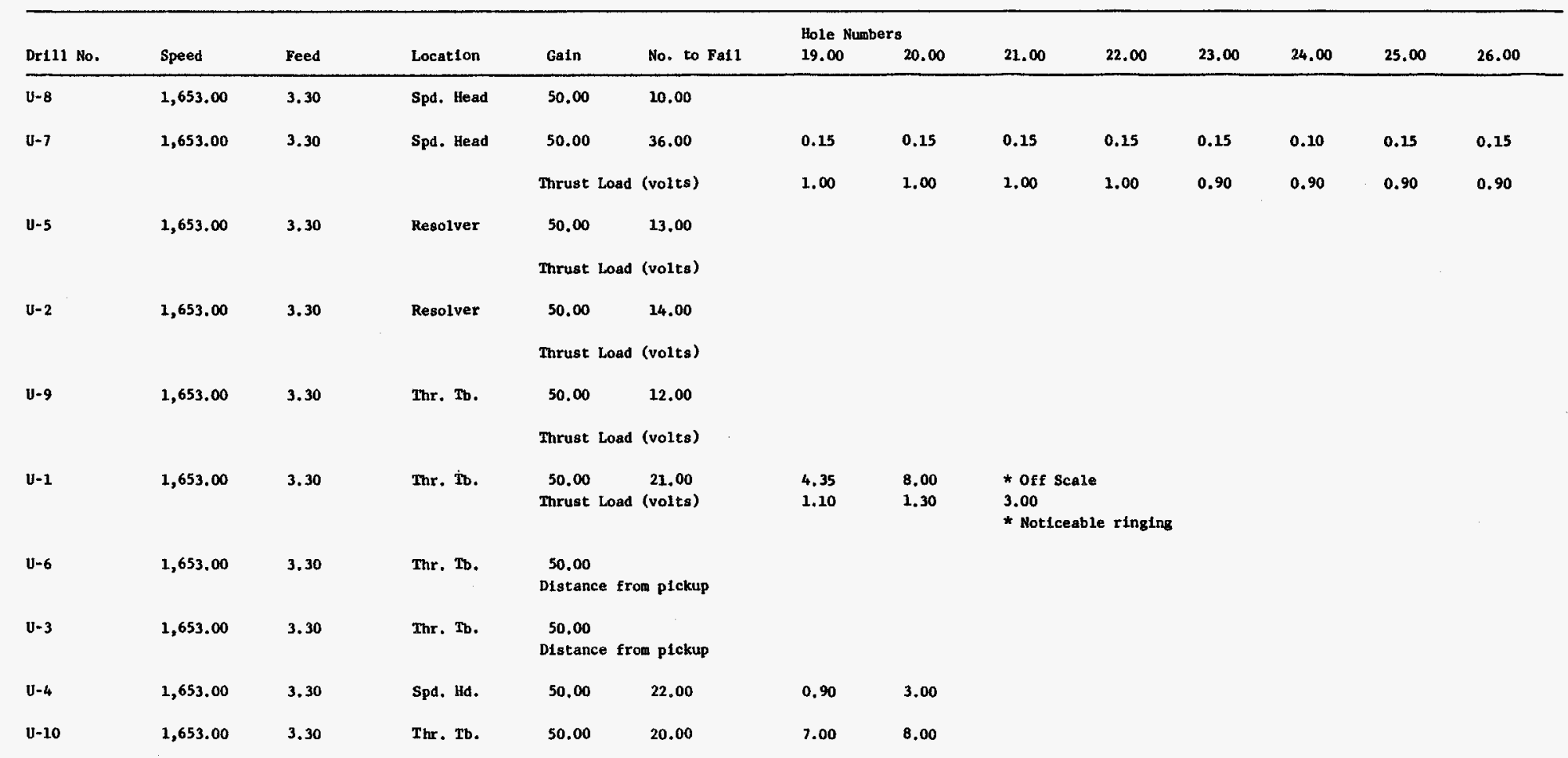


Table B-2, Continued. Acoustic Emission Preliminary Runs

0.203 in. Diameter Uncoated High Speed Steel Drills Determination of Transducer Location

\begin{tabular}{|c|c|c|c|c|c|c|c|c|c|c|c|c|c|c|}
\hline \multirow[b]{2}{*}{ Dri11 No. } & \multirow[b]{2}{*}{ Speed } & \multirow[b]{2}{*}{ Feed } & \multirow[b]{2}{*}{ Location } & \multirow[b]{2}{*}{ Gain } & \multirow[b]{2}{*}{ No. to Fall } & \multicolumn{3}{|c|}{ Hole Numbers } & \multirow[b]{2}{*}{13.00} & \multirow[b]{2}{*}{14.00} & & \multirow{2}{*}{16.00} & \multirow[b]{2}{*}{17.00} & \multirow[b]{2}{*}{18.00} \\
\hline & & & & & & 10.00 & 11.00 & 12.00 & & & 15.00 & & & \\
\hline U-8 & $1,653.00$ & 3.30 & Spd. Head & 50.00 & 10.00 & \multicolumn{8}{|c|}{ * Retracted spindle into housing and noticed tms value doubled. } & \\
\hline \multirow[t]{2}{*}{$U-7$} & $1,653.00$ & 3.30 & Spd. Head & 50.00 & 36.00 & 0.15 & 0.25 & 0.15 & 0.15 & 0.15 & 0.15 & 0.15 & 0.15 & 0.15 \\
\hline & & & & Thrust Load & (volts) & 0.95 & 0.95 & 0.95 & 0.95 & 1.00 & 1.00 & 1.00 & 1.00 & 1.00 \\
\hline \multirow[t]{3}{*}{ U-5 } & $1,653.00$ & 3.30 & Resolver & 50.00 & 13.00 & 1.10 & 1.10 & 1.40 & 8.00 & & & & & \\
\hline & & & & Thrust Load & (volts) & 1.10 & 1.10 & 1.30 & 2.00 & & & & & \\
\hline & & & & & & & & * : & * Noti & ble rin & 8 on $\mathrm{tr}$ & & & \\
\hline \multirow{2}{*}{ U-2 } & $1,653.00$ & 3.30 & Resolver & 50.00 & 14.00 & 1.15 & 1.15 & 1.10 & 1.20 & 6.80 & & & & \\
\hline & & & & Thrust Load & (volts) & 1.00 & 1.00 & 1.00 & 1.10 & 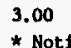 & le rin & g on $t$ & & \\
\hline
\end{tabular}

$\begin{array}{cccccc}\text { U-1 } & 1,653.00 & 3.30 & \text { Thr. Tb. } & \begin{array}{c}50.00 \\ \text { Thrust Load (volts) }\end{array} \\ \text { U-6 } & 1,653.00 & 3.30 & \text { Thr. Tb. } & \begin{array}{l}50.00 \\ \text { Distance from pickup }\end{array} \\ \text { U-3 } & 1,653.00 & 3.30 & \text { Thr. Tb. } & \begin{array}{c}50.00 \\ \text { Distance from pickup }\end{array} \\ \text { U-4 } & 1,653.00 & 3.30 & \text { Spd. Hd. } & 50.00 & 22.00 \\ \text { U-10 } & 1,653.00 & 3.30 & \text { Thr. Tb. } & 50.00 & 20.00\end{array}$

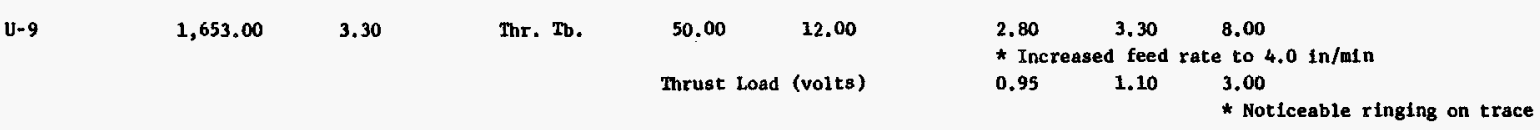

$*$ Increased feed rate to $4.0 \mathrm{in} / \mathrm{m} 1 \mathrm{n}$

$1,653.00 \quad 3,30$

$\begin{array}{lllllllll}0.80 & 0.90 & 0.85 & 0.85 & 0.90 & 0.90 & 0.90 & 0.90 & 0.90 \\ 1.40 & 1.50 & 1.50 & 2.60 & 1.70 & 2.80 & 2.40 & 2.40 & 2.60\end{array}$


Table B-2, Continued. Acoustic Emission Preliminary Runs

0.203 in. Diameter Uncoated High Speed Steel Drills

Determination of Transducer Location

\begin{tabular}{|c|c|c|c|c|c|c|c|c|c|c|c|c|c|c|c|c|}
\hline \multirow[b]{2}{*}{ Drill No. } & \multirow[b]{2}{*}{ Speed } & \multirow[b]{2}{*}{ Feed } & \multirow[b]{2}{*}{ Location } & \multirow[b]{2}{*}{ Gain } & \multirow[b]{2}{*}{ No, to Fat1 } & \multicolumn{2}{|c|}{ Hole Numbers } & \multirow[b]{2}{*}{29.00} & \multirow[b]{2}{*}{30.00} & \multirow[b]{2}{*}{31.00} & \multirow[b]{2}{*}{32.00} & \multirow[b]{2}{*}{33.00} & \multirow[b]{2}{*}{34,00} & \multirow[b]{2}{*}{35.00} & \multirow[b]{2}{*}{36.00} & \multirow[b]{2}{*}{37.00} \\
\hline & & & & & & 27.00 & 28.00 & & & & & & & & & \\
\hline $\mathrm{U}-8$ & $1,653.00$ & 3.30 & Spd. Head & 50.00 & 10.00 & & & & & & & & & & & \\
\hline \multirow[t]{2}{*}{$\mathrm{U}-7$} & $1,653.00$ & 3.30 & Spd. Head & 50.00 & 36.00 & 0.15 & 0.15 & 0.15 & 0.15 & 0.15 & 0.15 & 0.15 & 0.10 & 0.15 & 3.50 & \\
\hline & & & & \multicolumn{2}{|c|}{ Thrust Load (volts) } & 0.95 & 0.95 & 0.95 & 0.95 & 0.95 & $\begin{array}{l}0.95 \\
\text { Noticeab }\end{array}$ & $\begin{array}{l}0.95 \\
\text { ringing }\end{array}$ & $\begin{array}{l}1.00 \\
\text { trace }\end{array}$ & $\begin{array}{l}1.40 \\
*\end{array}$ & $\begin{array}{l}2.00 \\
\star\end{array}$ & \\
\hline
\end{tabular}

\begin{tabular}{|c|c|c|c|c|}
\hline \multirow[t]{2}{*}{ U-5 } & $1,653.00$ & 3.30 & Resolver & 50.00 \\
\hline & & & & Thrust Load (volts) \\
\hline \multirow[t]{2}{*}{$\mathrm{U}-2$} & $1,653.00$ & 3.30 & Resolver & 14.00 \\
\hline & & & & Thrust Load (volts) \\
\hline \multirow[t]{2}{*}{ d-9 } & $1,653.00$ & 3.30 & Thr. Tb. & 12.00 \\
\hline & & & & Thrust Load (volts) \\
\hline \multirow[t]{2}{*}{$\mathrm{v}-1$} & $1,653.00$ & 3.30 & Thr. Tb. & 21.00 \\
\hline & & & & Inrust Load (voits) \\
\hline$u-6$ & $1,653.00$ & 3.30 & Thr. Tb. & $\begin{array}{l}50,00 \\
\text { Distance from pickup }\end{array}$ \\
\hline $\mathrm{U}-\mathbf{3}$ & $1,653.00$ & 3.30 & Thr, Tb. & $\begin{array}{l}50.00 \\
\text { Distance from pickup }\end{array}$ \\
\hline$U-4$ & $1,653.00$ & 3.30 & Spd. Hd. & 22.00 \\
\hline U-10 & $1,653.00$ & 3.30 & Thr. Tb. & 50.00 \\
\hline
\end{tabular}


Table B-3. Acoustic Emission Statistical Screening Test

0.033 in. Diameter Drills Both High Speed Steel and Carbide

\begin{tabular}{|c|c|c|c|c|c|c|c|c|c|c|c|c|c|}
\hline $\begin{array}{l}\text { Drill } \\
\text { No. }\end{array}$ & $\begin{array}{l}\text { Speed } \\
\text { (RPM) }\end{array}$ & $\begin{array}{l}\text { Feed } \\
(\text { in/min })\end{array}$ & Material & $\begin{array}{l}\text { Galn } \\
(D b)\end{array}$ & $\begin{array}{l}\text { No, of thole } \\
\text { Fai lure }\end{array}$ & $\begin{array}{l}\text { Hole } \\
10.00\end{array}$ & 85.00 & 20.00 & 25.00 & 30.00 & 35,00 & 40.00 & 45.00 \\
\hline 1.00 & $9,042.00$ & 2.40 & HSS & 74.00 & 14.00 & 0.60 & $\begin{array}{r}12.00 \\
1.10\end{array}$ & $\begin{array}{r}23.00 \\
0.90\end{array}$ & $\begin{array}{r}14.00 \\
4.00\end{array}$ & & & & \\
\hline 2.00 & $9,042.00$ & 6.80 & HSS & 70.00 & 28.00 & 0.70 & 0.50 & 1.50 & 1.30 & $\begin{array}{r}28.00 \\
3.10\end{array}$ & & & \\
\hline 3.00 & 9,042 & 6.80 & Carbide & 70.00 & 105.00 & 1.00 & 1.70 & 0.95 & 0.80 & 1.40 & 0.90 & 1.20 & 1.10 \\
\hline 4.00 & 6,366 & 5.70 & Carbide & 70.00 & 47.00 & 0.80 & 0.70 & 0.60 & 0.60 & 0.60 & 0.80 & 0.70 & 0.60 \\
\hline 5.00 & 6,366 & 5.07 & Hss & 70.00 & 21.00 & 0.25 & 0.45 & 0.65 & & & & & \\
\hline 6.00 & 6,366 & 2.40 & Carbide & 74.00 & 88.00 & 0.90 & 0.40 & 0.40 & 0.50 & 0.90 & 0.80 & 0.50 & 0.60 \\
\hline 7.00 & 9,042 & 2.40 & Carbide & 74.00 & 75,00 & 1.00 & 1.20 & 1.70 & 1.00 & 1.70 & 2.10 & 1.30 & 1.30 \\
\hline 8.00 & 6,366 & 2.40 & HSS & 76.00 & 21.00 & 0.75 & 0.60 & 0.60 & 0.60 & & & & \\
\hline 9.00 & 9,042 & 5.70 & Carbide & 70.00 & 103.00 & 0.30 & 0.30 & 0.40 & 0.40 & 0.40 & 0.40 & 0.40 & 0.40 \\
\hline 10.00 & 9,042 & 5.70 & HSS & 74.00 & 26.00 & 0.70 & 6.00 & 0.90 & 1.00 & & & & \\
\hline
\end{tabular}


Table B-3, Continued. Acoustic Emission Statistical Screening Test

0.033 in. Diameter Drills Both High Speed Steel and Carbide

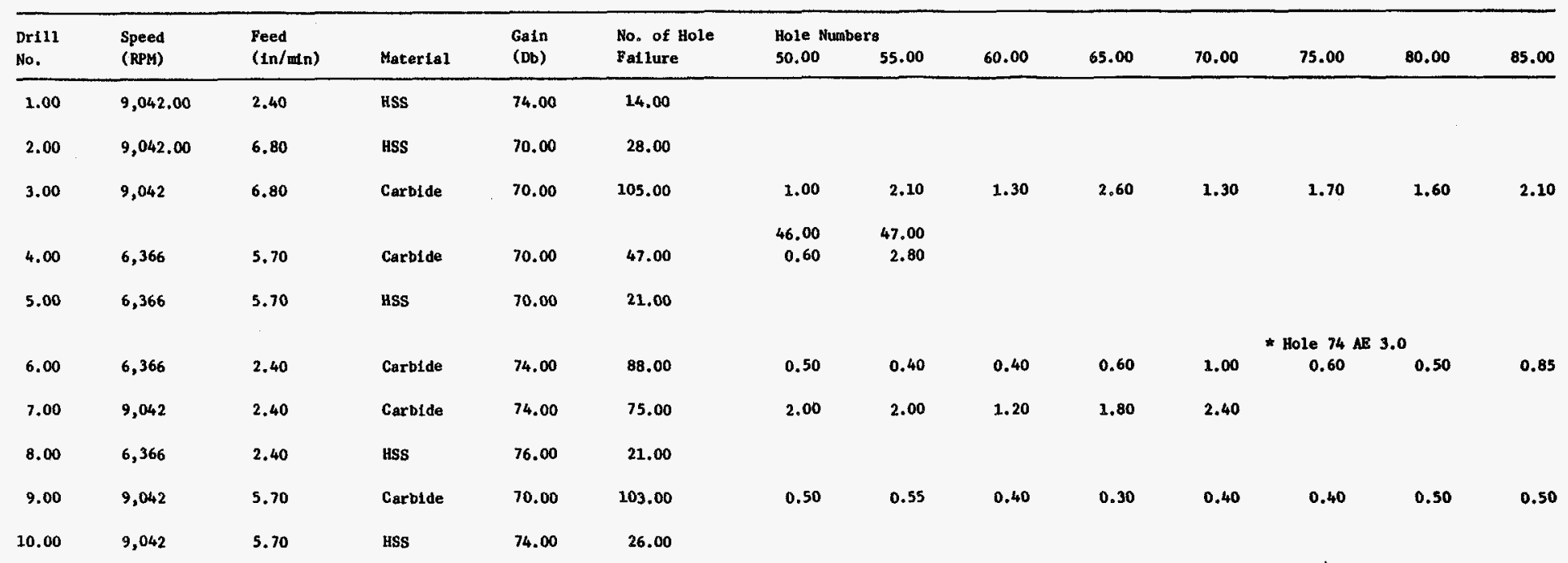


Table B-3, Continued. Acoustic Emission Statistical Screening Test
0.033 in. Diameter Drills Both High Speed Steel and Carbide

\begin{tabular}{|c|c|c|c|c|c|c|c|c|c|c|c|c|}
\hline $\begin{array}{l}\text { Drill } \\
\text { No. }\end{array}$ & $\begin{array}{l}\text { Speed } \\
\text { (RPM) }\end{array}$ & $\begin{array}{l}\text { Eeed } \\
\text { (In/min) }\end{array}$ & MaterLa1 & $\begin{array}{l}\text { Gain } \\
\text { (Db) }\end{array}$ & $\begin{array}{l}\text { No. of Hole } \\
\text { FaLlure }\end{array}$ & $\begin{array}{l}\text { Hole Numbers } \\
90.00\end{array}$ & 95.00 & 100.00 & 105.00 & 110.00 & 115.00 & 120.00 \\
\hline 1.00 & $9,042.00$ & 2.40 & HSS & 74.00 & 14.00 & & & & & & & \\
\hline 2.00 & $9,042,00$ & 6.80 & HSS & 70.00 & 28.00 & & & & & & & \\
\hline 3.00 & 9,042 & 6.80 & Carbide & 70.00 & 105.00 & 1.70 & 2.00 & 2.00 & 2.20 & & & \\
\hline 4.00 & 6,366 & 5.70 & Carbide & 70.00 & 47.00 & & & & & & & \\
\hline 5.00 & 6,366 & 5.70 & HSS & 70.00 & 21.00 & & & & & & & \\
\hline 6.00 & 6,366 & 2.40 & Carbide & 74.00 & 88.00 & $\begin{array}{r}87.00 \\
6.00\end{array}$ & $\begin{array}{l}88.00 \\
\text { Broke }\end{array}$ & & & & & \\
\hline 7.00 & 9,042 & 2.40 & Garbide & 74.00 & 75.00 & & & & & & & \\
\hline 8.00 & 6,366 & 2.40 & HSS & 76.00 & 21.00 & & & & & & & \\
\hline $9.00 !$ & 9,042 & 5.70 & Carbide & 70.00 & 103.00 & 0.70 & 0.60 & 2.00 & $\begin{array}{r}103.00 \\
6.00\end{array}$ & & & \\
\hline 10.00 & 9,042 & 5.70 & HSS & 74.00 & 26.00 & & & & & & & \\
\hline
\end{tabular}


Table B-4. Acoustic Emission Statistical Screening Test

0.093 in. Diameter Drills Both High Speed Steel and Carbide

\begin{tabular}{|c|c|c|c|c|c|c|c|c|c|c|c|c|c|c|c|}
\hline $\begin{array}{l}\text { Dri11 } \\
\text { Ho. }\end{array}$ & $\begin{array}{l}\text { Speed } \\
\text { (RPM) }\end{array}$ & $\begin{array}{l}\text { Feed } \\
(\text { in } / \mathrm{m} / \mathrm{n})\end{array}$ & Material & $\begin{array}{l}\text { Gain } \\
(\mathrm{Db})\end{array}$ & $\begin{array}{l}\text { No. of Hole } \\
\text { Fallure }\end{array}$ & $\begin{array}{l}\text { Hole } \\
1.00\end{array}$ & 5.00 & 10.00 & 15.00 & 20.00 & 25.00 & 30.00 & 35.00 & 40.00 & 45.00 \\
\hline 1.00 & $1,507,00$ & 4.50 & Carbide & 60.00 & 3.00 & 1.30 & $\begin{array}{l}2.00 \\
1.65\end{array}$ & $\begin{array}{l}3.00 \\
4.50\end{array}$ & & & & & & & \\
\hline 2.00 & $3,500,00$ & 5.20 & Carbide & 60.00 & 35.00 & 0.85 & 0.90 & 0.80 & 0,80 & 0.80 & 1.45 & 2.40 & $\begin{array}{r}34.00 \\
4.50\end{array}$ & $\begin{array}{r}35.00 \\
7.00\end{array}$ & \\
\hline 3.00 & $1,507,00$ & 5,20 & HSS & 60.00 & 10.00 & 1.20 & 1.90 & $\begin{array}{l}9.00 \\
6.00\end{array}$ & $\begin{array}{r}10.00 \\
7.00\end{array}$ & & & & & & \\
\hline 4.00 & $1,507.00$ & 4.50 & HSS & 60,00 & 33.00 & 0.50 & 0.80 & 1.10 & 1.10 & 1.20 & 1.10 & 1.10 & $\begin{array}{r}32.00 \\
2.70\end{array}$ & $\begin{array}{r}33.00 \\
4.00\end{array}$ & \\
\hline 5.00 & $1,507.00$ & 2.30 & HSS & 66.00 & 69.00 & 1.20 & 2.50 & 2.70 & 2.90 & 2.85 & 2.75 & 2.75 & 3.00 & 2.80 & 2.85 \\
\hline 6.00 & $3,500.00$ & 4.50 & Carbide & 60.00 & 45.00 & 0.40 & 0.50 & 0.50 & 0.90 & 0.70 & 0.70 & 3.60 & 2.50 & 6.00 & \\
\hline 7.00 & $3,500.00$ & 4.50 & HSS & 60.00 & 114.00 & 0.45 & 0.40 & 0.40 & 0.40 & 0.40 & 0.40 & 0.40 & 0.40 & 0.50 & 0.40 \\
\hline 8.00 & $3,500,00$ & 2.30 & Carbide & 66.00 & 59.00 & 1.40 & 0.90 & 1.80 & 1.90 & 6.00 & 3.30 & 3.40 & 3.50 & 3.50 & 6.00 \\
\hline 9.00 & $3,500.00$ & 5.20 & Hss & 60.00 & 25.00 & 0.55 & 0.40 & 0.45 & 0.55 & 0.55 & $\begin{array}{r}23.00 \\
1.50\end{array}$ & $\begin{array}{r}24.00 \\
2.10\end{array}$ & $\begin{array}{r}25.00 \\
7.00\end{array}$ & & \\
\hline 10.00 & $3,500,00$ & 5.20 & Carbide & 60.00 & 42.00 & 0.35 & 0.40 & 0.40 & 0.65 & 0.55 & 0.60 & 0.95 & 1.50 & 1.70 & $\begin{array}{r}42.00 \\
5.00\end{array}$ \\
\hline 11.00 & $1,507.00$ & 2.30 & Carbide & 60.00 & 55.00 & 0.30 & 0.30 & 0.40 & 0.55 & 0.40 & 1.10 & 2.40 & 3.80 & 2.30 & 2.90 \\
\hline 12.00 & $3,500.00$ & 2.30 & HSS & 66.00 & 21.00 & 1.60 & 1.70 & 2.00 & 3.60 & 4.90 & $\begin{array}{r}21.00 \\
7.00\end{array}$ & & & & \\
\hline
\end{tabular}


Table B-4, Continued. Acoustic Emission Statistical Screening Test

0.093 in. Diameter Drills Both High Speed Steel and Carbide

\begin{tabular}{|c|c|c|c|c|c|c|c|c|c|c|c|c|c|}
\hline $\begin{array}{l}\text { Dr111 } \\
\text { No. }\end{array}$ & $\begin{array}{l}\text { Speed } \\
\text { (RPM) }\end{array}$ & $\begin{array}{l}\text { Feed } \\
(\mathrm{in} / \mathrm{m} \mathbf{m} n)\end{array}$ & Mater $1 \mathrm{a} 1$ & $\begin{array}{l}\text { Gain } \\
(\mathrm{DD})\end{array}$ & $\begin{array}{l}\text { No. of Hole } \\
\text { Fail lure }\end{array}$ & $\begin{array}{l}\text { Hole } \mathrm{N} \\
50.00\end{array}$ & 55.00 & 60.00 & 65.00 & 70.00 & 75.00 & 80.00 & 85.00 \\
\hline 1.00 & $1,507.00$ & 4.50 & Carbide & 60.00 & 3.00 & & & & & & & & \\
\hline 2.00 & $3,500.00$ & 5.20 & Carblde & 60.00 & 35.00 & & & & & & & & ' \\
\hline 3.00 & $1,507.00$ & 5.20 & HSS & 60.00 & 10.00 & & & & & & & & \\
\hline 4.00 & $1,507.00$ & 4.50 & HSS & 60.00 & 33.00 & & & & & & & & \\
\hline 5.00 & $1,507.00$ & 2.30 & HSS & 66.00 & 69.00 & 3.25 & 2.90 & 2.70 & 4.20 & $\begin{array}{r}66.00 \\
* \\
* A E\end{array}$ & $\begin{array}{c}67.00 \\
* \\
\text { off scale }\end{array}$ & $\begin{array}{c}68,00 \\
\star\end{array}$ & $\begin{array}{l}69.00 \\
\star\end{array}$ \\
\hline 6,00 & $3,500,00$ & 4.50 & Carblde & 60.00 & 45.00 & & & & & & & & \\
\hline 7.00 & $3,500.00$ & 4.50 & HSS & 60.00 & 114.00 & 0.45 & 0.50 & 0.50 & 0.50 & 0.50 & 0.60 & 0.50 & 0.70 \\
\hline 8.00 & $3,500,00$ & 2.30 & Carbide & 66.00 & 59.00 & 6.00 & 6.00 & $\begin{array}{r}59.00 \\
8.00\end{array}$ & & & & & \\
\hline 9.00 & $3,500.00$ & 5.20 & HSS & 60.00 & 25.00 & & & & & & & & \\
\hline 10.00 & $3,500,00$ & 5.20 & carbide & 60.00 & 42.00 & & & & & & & & \\
\hline 11.00 & $1,507.00$ & 2.30 & Carbide & 60.00 & 55.00 & 1.50 & $\begin{array}{r}53.00 \\
3.60\end{array}$ & $\begin{array}{r}54.00 \\
2.10\end{array}$ & $\begin{array}{r}55.00 \\
7.00\end{array}$ & & & & \\
\hline 12.00 & $3,500,00$ & 2.30 & HSS & 66.00 & 21.00 & & & & & & & & \\
\hline
\end{tabular}


Table B-4, Continued. Acoustic Emission Statistical Screening Test

0.093 in. Diameter Drills Both High Speed Steel and Carbide

\begin{tabular}{|c|c|c|c|c|c|c|c|c|c|c|c|c|}
\hline $\begin{array}{l}\text { Drill } \\
\text { No. }\end{array}$ & $\begin{array}{l}\text { Speed } \\
\text { (RPM) }\end{array}$ & $\begin{array}{l}\text { Feed } \\
\text { (In/mIn) }\end{array}$ & Mater Ial & $\begin{array}{l}\text { Gain } \\
(D b)\end{array}$ & $\begin{array}{l}\text { No. of Hole } \\
\text { Fail lure }\end{array}$ & $\begin{array}{l}\text { Ho1e Numbers } \\
90.00\end{array}$ & 95.00 & 100.00 & 105.00 & 110.00 & 115.00 & 120.00 \\
\hline 1.00 & $1,507.00$ & 4.50 & Carblde & 60.00 & 3.00 & & & & & & & \\
\hline 2.00 & $3,500.00$ & 5.20 & Carbide & 60.00 & 35.00 & & & & & & & \\
\hline 3.00 & $1,507.00$ & 5.20 & HSS & 60.00 & 10.00 & & & & & & & \\
\hline 4.00 & $1,507.00$ & 4.50 & HSS & 60.00 & 33.00 & & & & & & & \\
\hline 5.00 & $1,507.00$ & 2.30 & HSS & 66.00 & 69.00 & & & & & & & \\
\hline 6.00 & $3,500.00$ & 4.50 & Carbide & 60.00 & 45.00 & & & & & & & \\
\hline 7.00 & $3,500.00$ & 4.50 & HSS & 60.00 & 114.00 & 1.50 & 0.40 & 0.40 & 5.20 & 0.50 & $\begin{array}{r}113.00 \\
5.00\end{array}$ & $\begin{array}{r}114.00 \\
7.50\end{array}$ \\
\hline 8.00 & $3,500.00$ & 2.30 & Carbide & 66.00 & 59.00 & & & & & & & \\
\hline 9.00 & $3,500.00$ & 5.20 & HSS & 60.00 & 25.00 & & & & & & & \\
\hline 10.00 & $3,500.00$ & 5,20 & Carbide & 60.00 & 42.00 & & & & & & & \\
\hline 11.00 & $1,507.00$ & 2.30 & Carbide & 60.00 & 55.00 & & & & & & & \\
\hline 12.00 & $3,500.00$ & 2.30 & HsS & 66.00 & 21.00 & & & & & & & \\
\hline
\end{tabular}


Appendix C

TURNING TEST DATA 
The turning test was designed with the following insert and holder types so that the effects of tool geometry, nose radius, cutting speed, feed rate and depth of cut could be related to surface finish and insert wear.

Table $\mathrm{C}-1$ is a summary of the turning tool parameters.

The abbreviations on the data sheet are defined as follows:

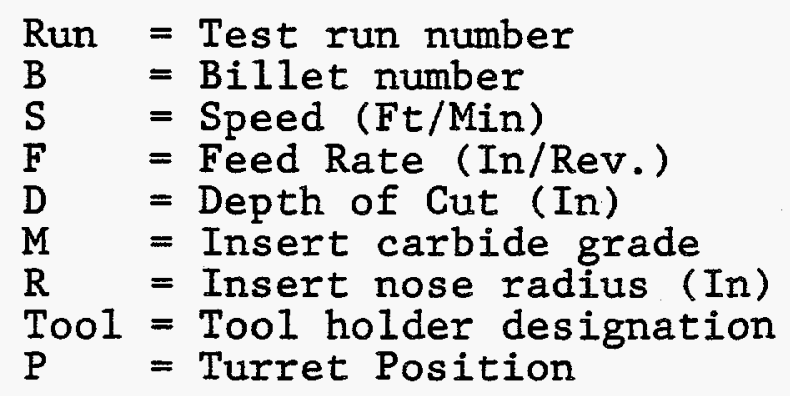


Table C-1. Cutting Tool Definition

\begin{tabular}{lrlcll}
\hline Description & Lead & $\begin{array}{l}\text { Angle } \\
\text { Back Rake }\end{array}$ & Side Rake & $\begin{array}{l}\text { Insert } \\
\text { Type }\end{array}$ & $\begin{array}{l}\text { Carbide } \\
\text { Grade }\end{array}$ \\
\hline KTAR-1230 Pos. & 0 & 0 & 0 & TPG-321,2 & C-2,3 \\
KTBR-1230 Pos. & 15 & 0 & 5 & TPG-321,2 & C-2,3 \\
KTAR-123 Neg. & 0 & -5 & -5 & TNG-321,2 & C-2,3 \\
KTAR-123 Neg. & 15 & -5 & -5 & TNG-321,2 & C-2, 3 \\
CTAAR-12-3 Hi-Pos. & 0 & 15 & 15 & TFG-321,2 & C-2,3 \\
CTAAR-12-3 Hi-Pos. & 15 & 15 & 15 & TFG-321,2 & C-2,3 \\
\hline
\end{tabular}




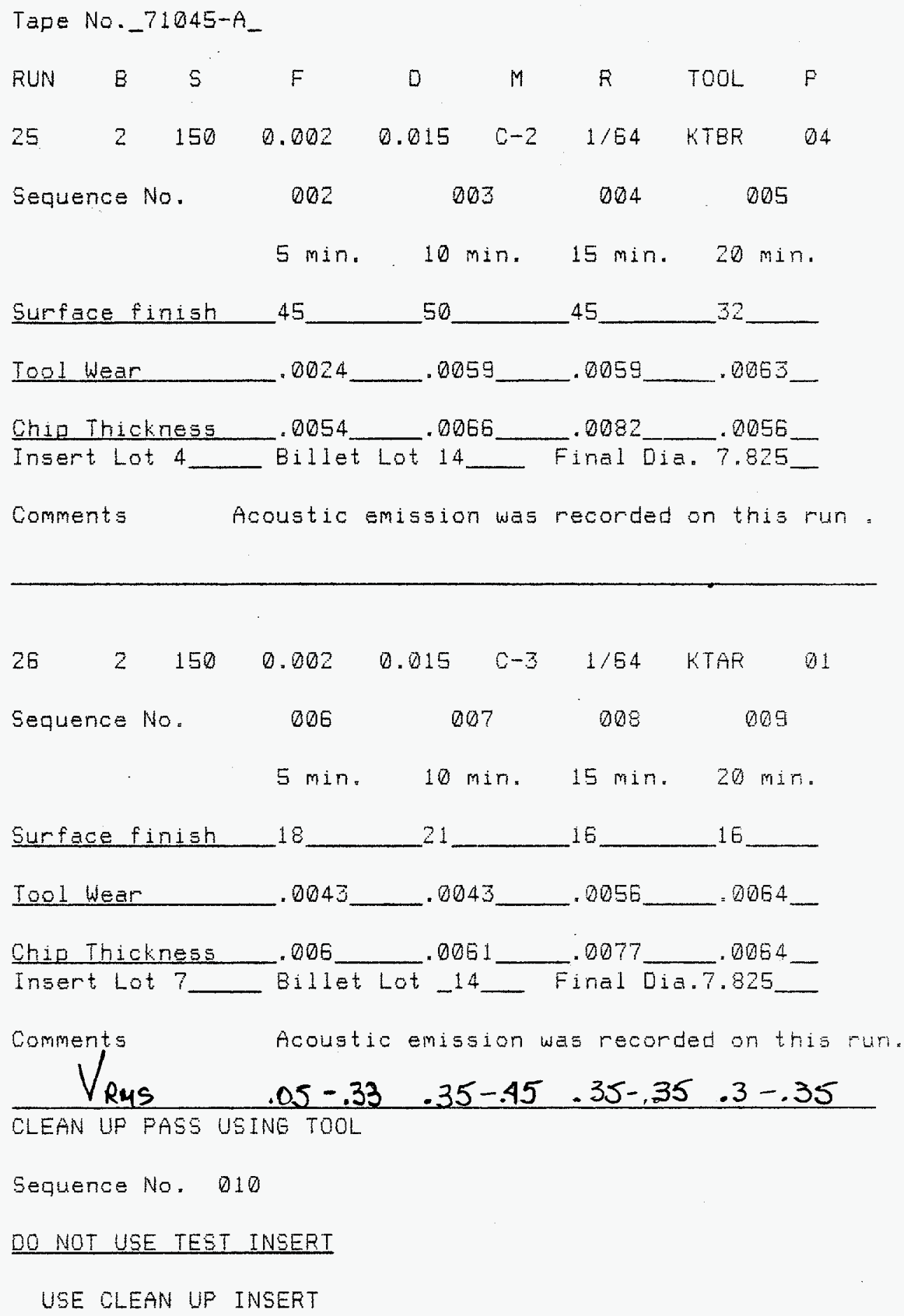
.0056 .0064

Chip Thickness .006 .0061 .0077 .0064 Insert Lot 7 Billet Lot -14 Final Dia.7.825

Comments Acoustic emission was recorded on this run.

CLEAN UP PASS USING TOOL

Sequence No. 010

DO NOT USE TEST INSERT

USE CLEAN UP INSERT 


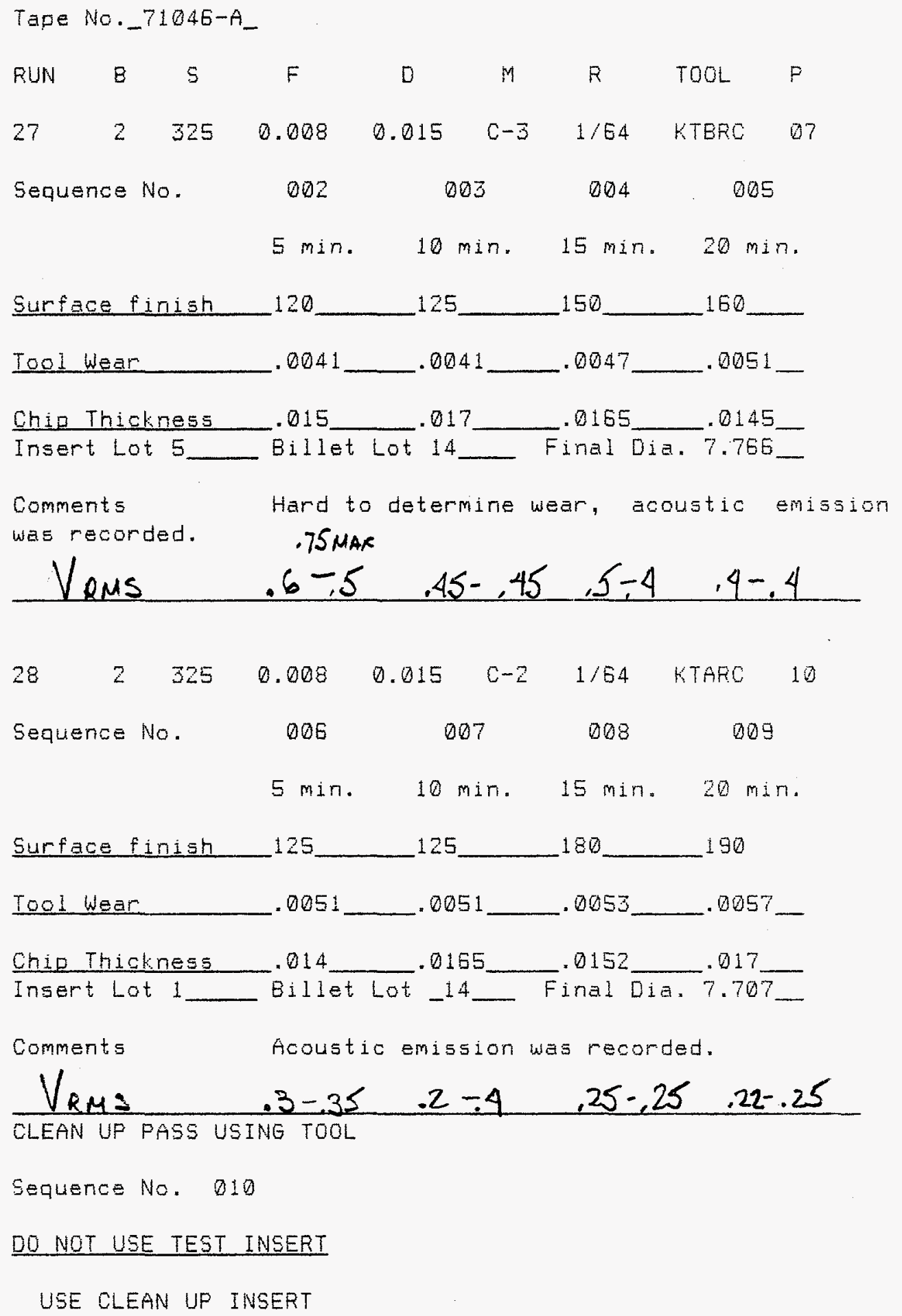




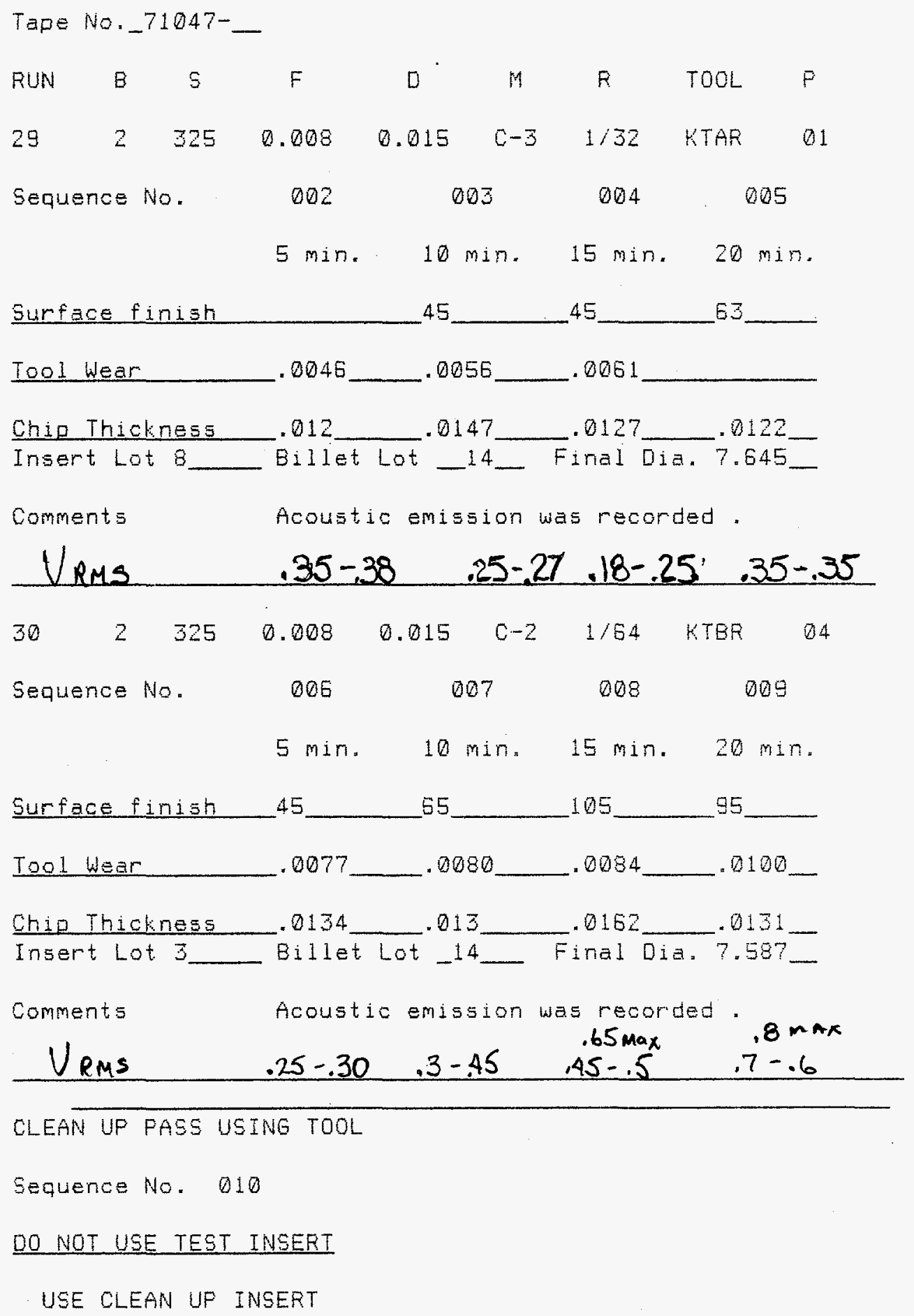




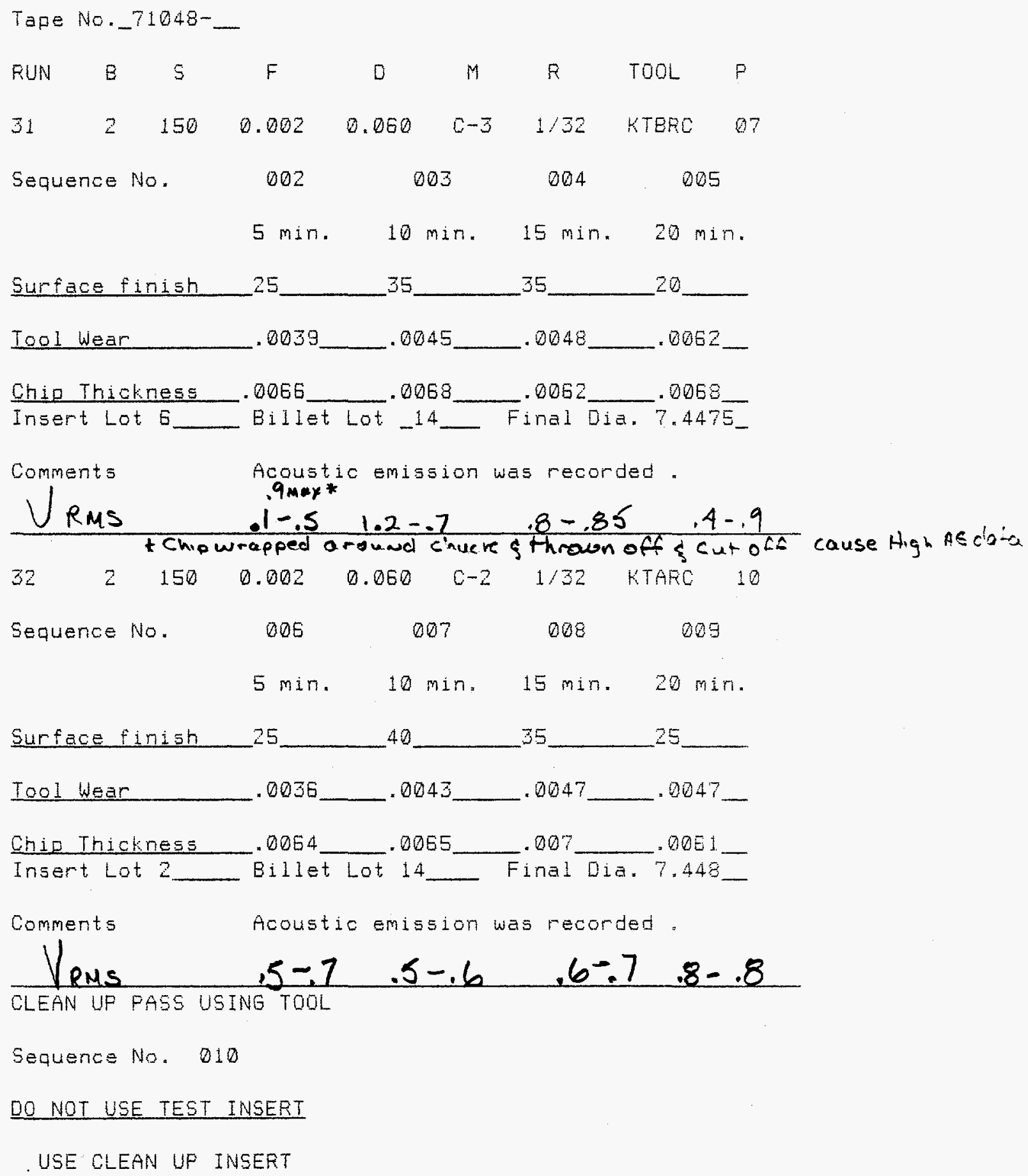


Tape No. $71049-$

$\begin{array}{ccccccccc}\text { RUN } & B & S & F & 0 & M & R & \text { TOOL } & P \\ 33 & 2 & 150 & 0.002 & 0.060 & C-3 & 1 / 64 & \text { CTBAR } & 01 \\ \text { Sequence No. } & 002 & 003 & 004 & 005 \\ & & 5 \mathrm{~min} . & 10 \mathrm{~min} . & 15 \mathrm{~min} . & 20 \mathrm{~min} .\end{array}$

Surface finish 30 20 18 22

Tool wear

Chip Thickness .0051

Insert Lot -12 Billet Lot_i4 Final Dia.

Comments Tool chiped out in the first 5 min, it may have been when burr was removed. The insert was indexed and the test restarted. This edge failed because wear couldn"t be definded. Thier was a big change or difference in acoustic emission between the lst and 2 nd cutting edge. The insert was indexed to the 3 rd edge for the last $5 \mathrm{~min}$.

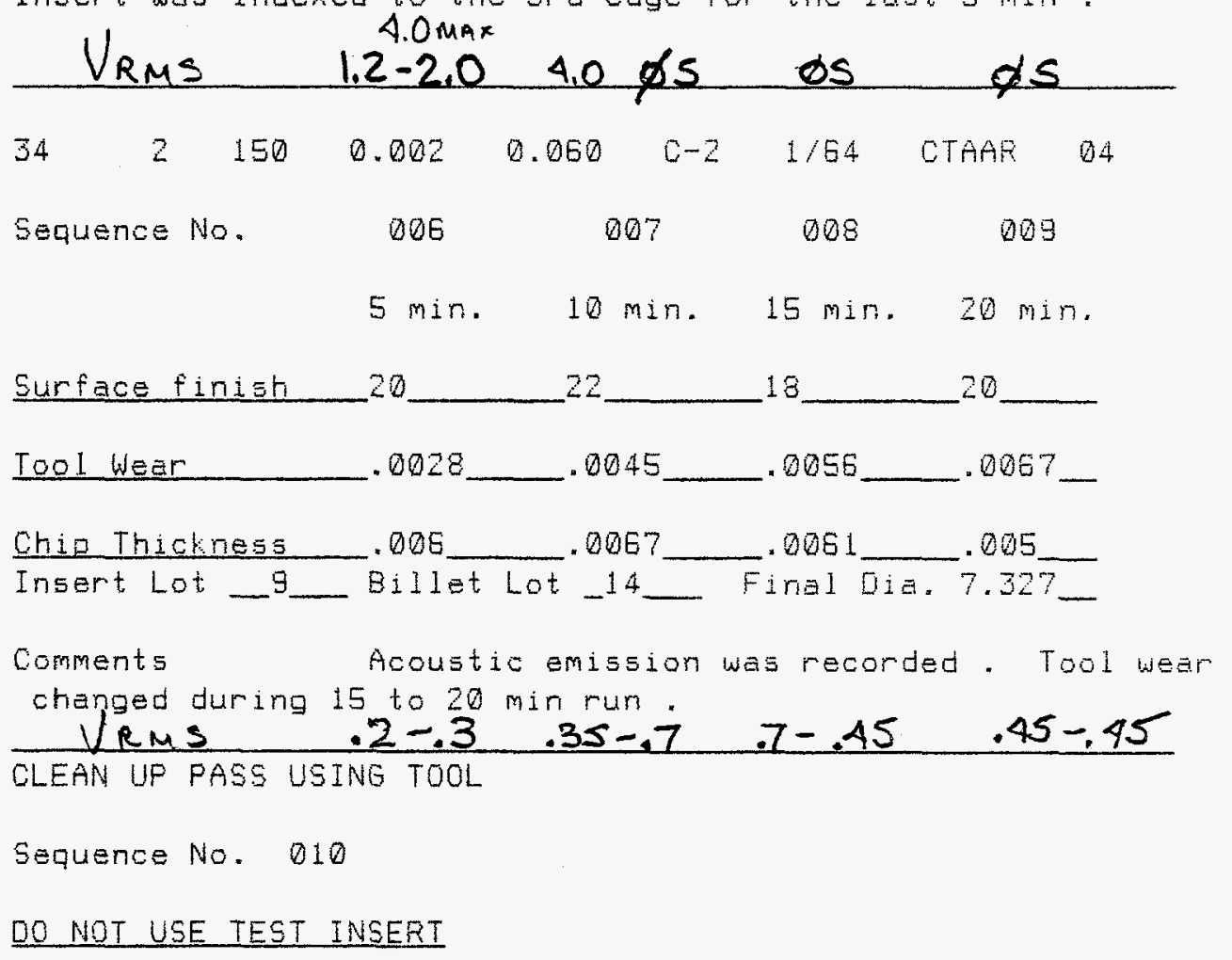

USE CLEAN UP INSERT 
Tape No. $71050-$

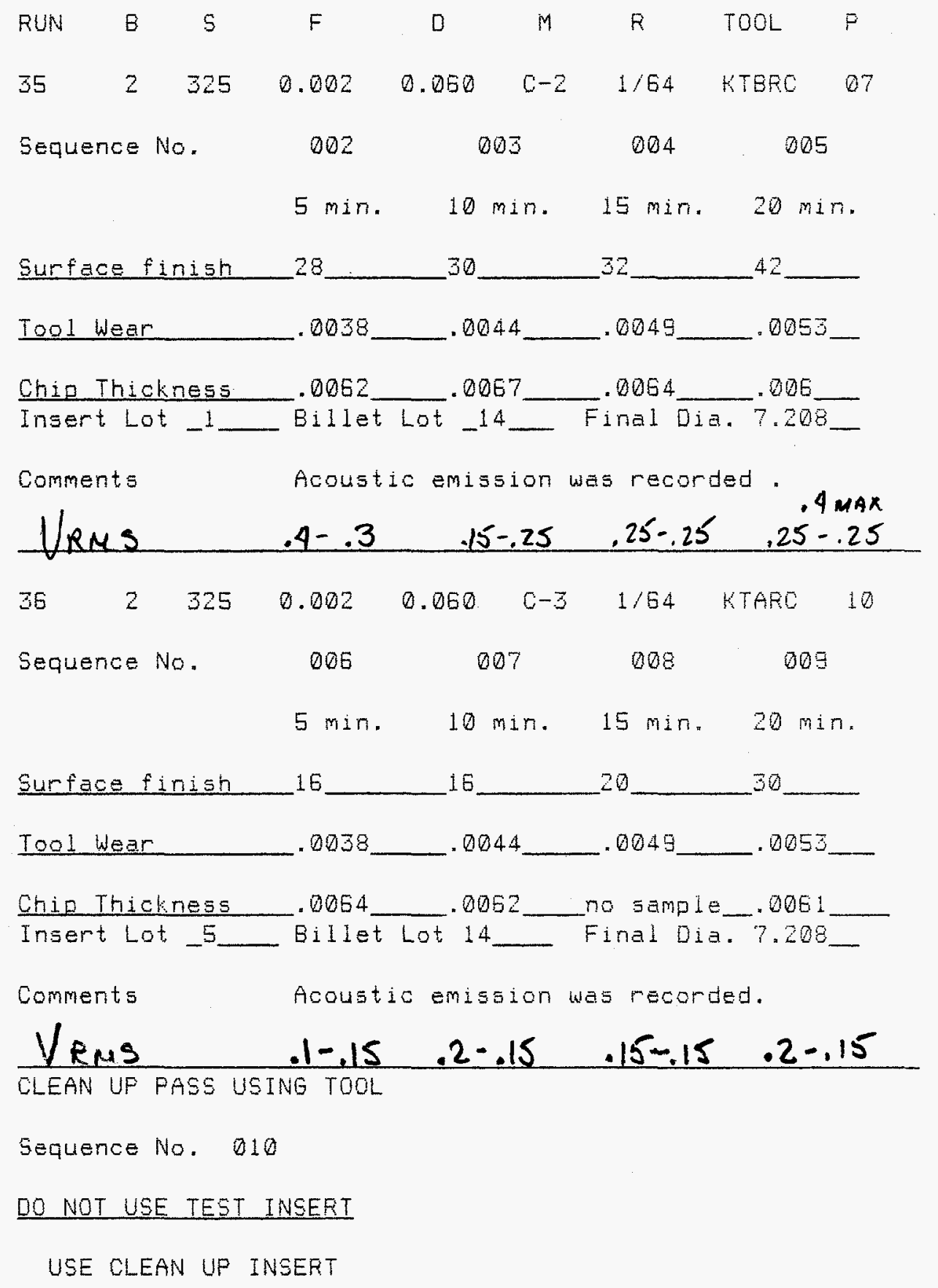




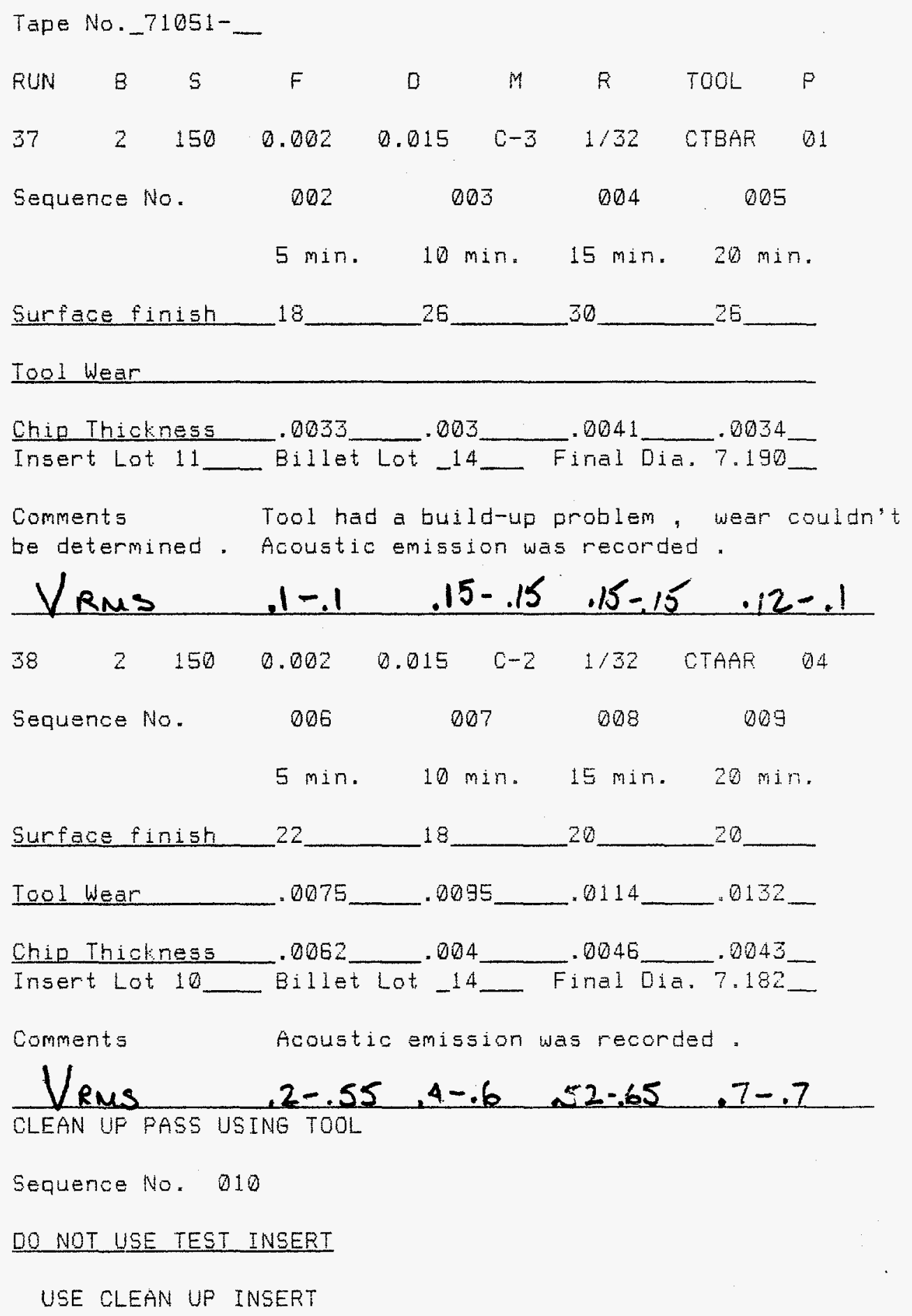




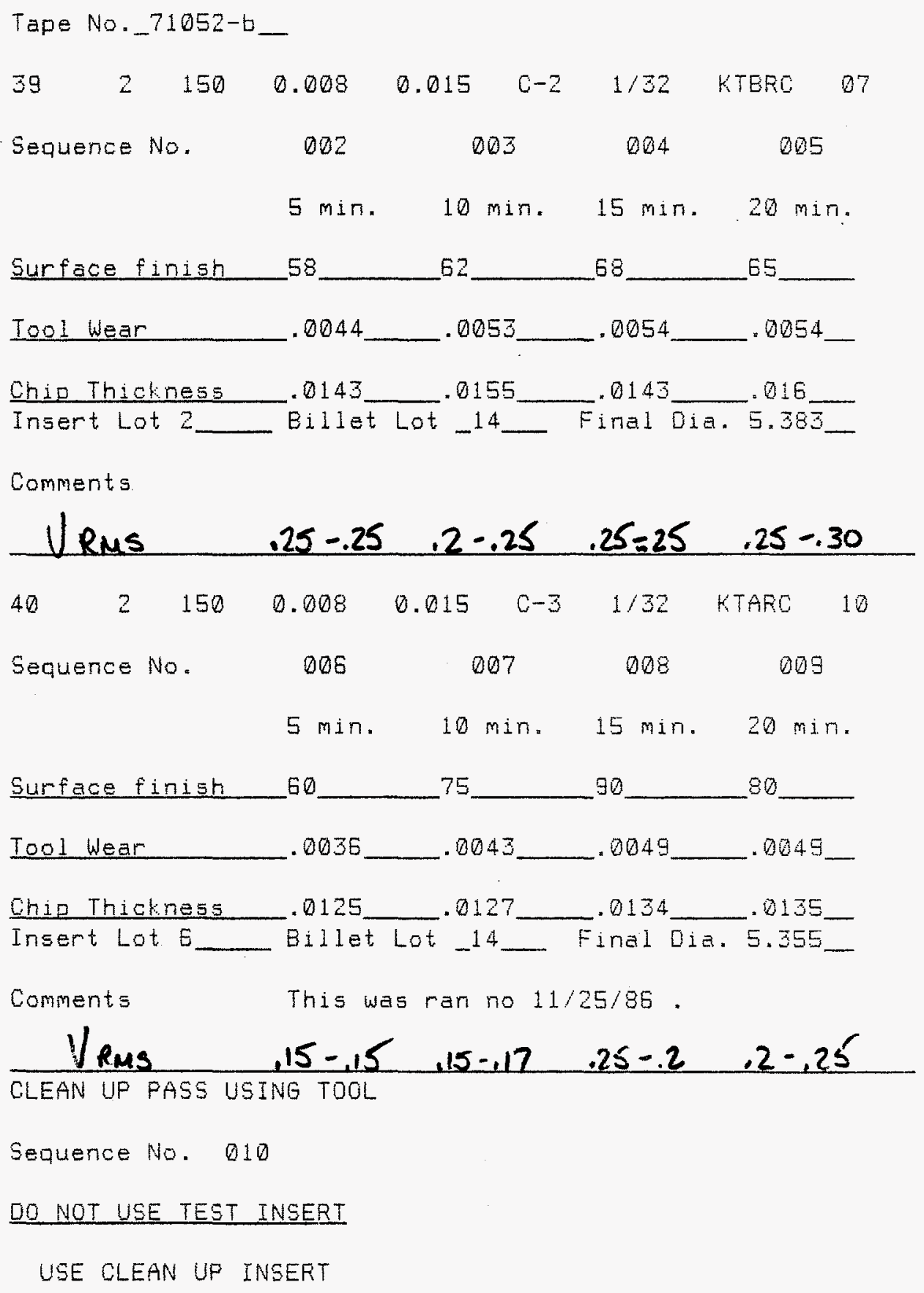




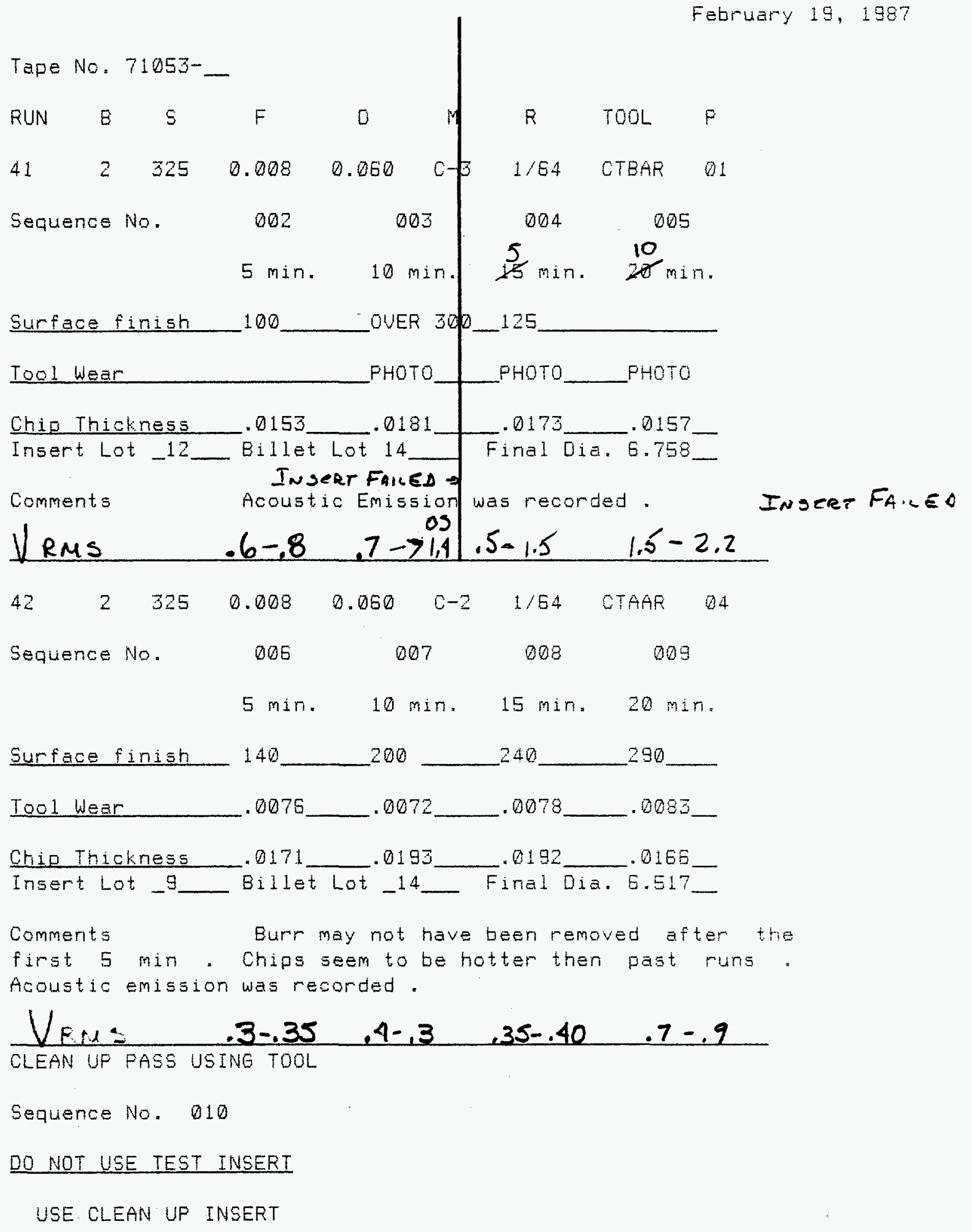


Tape No. 71054

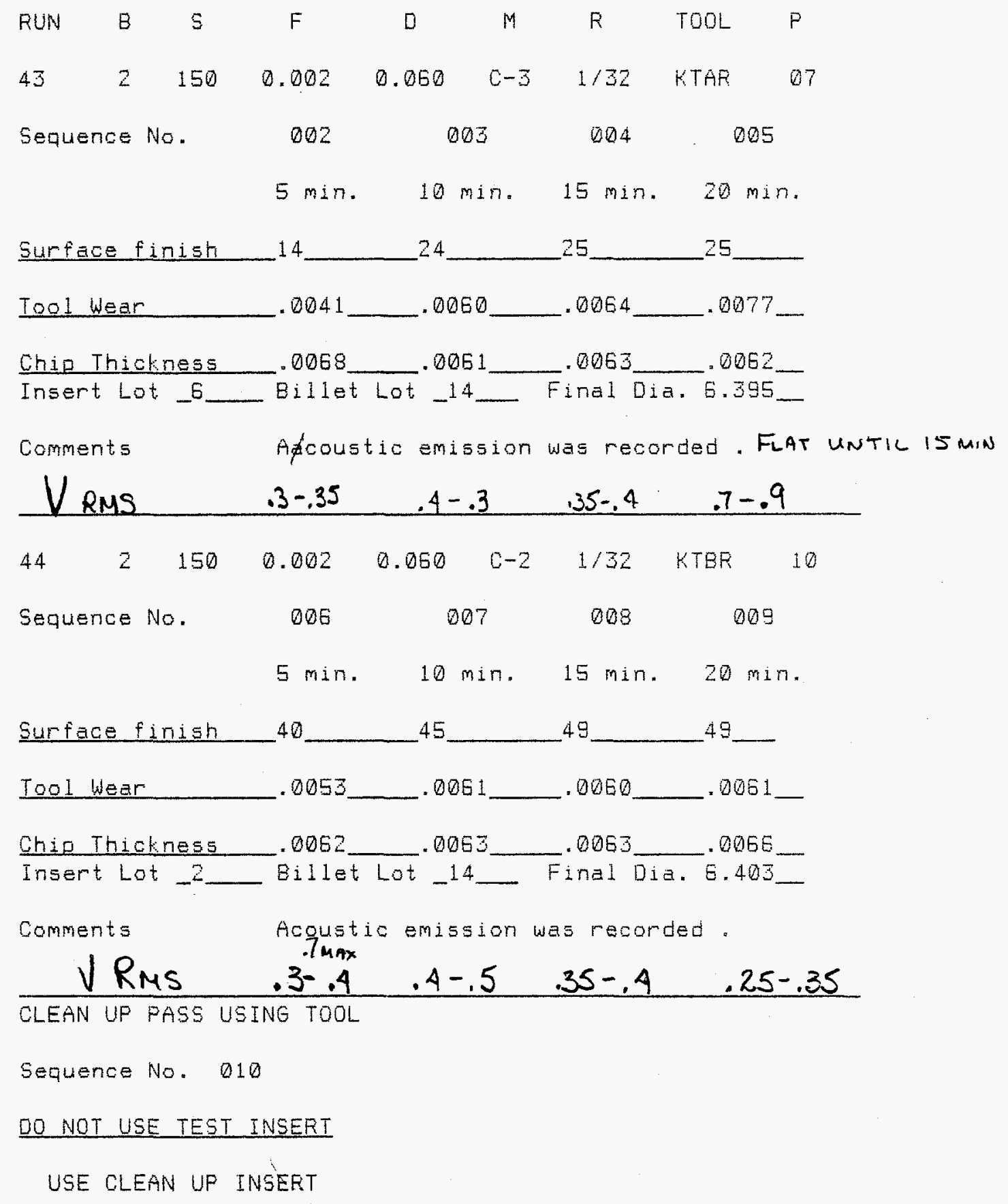




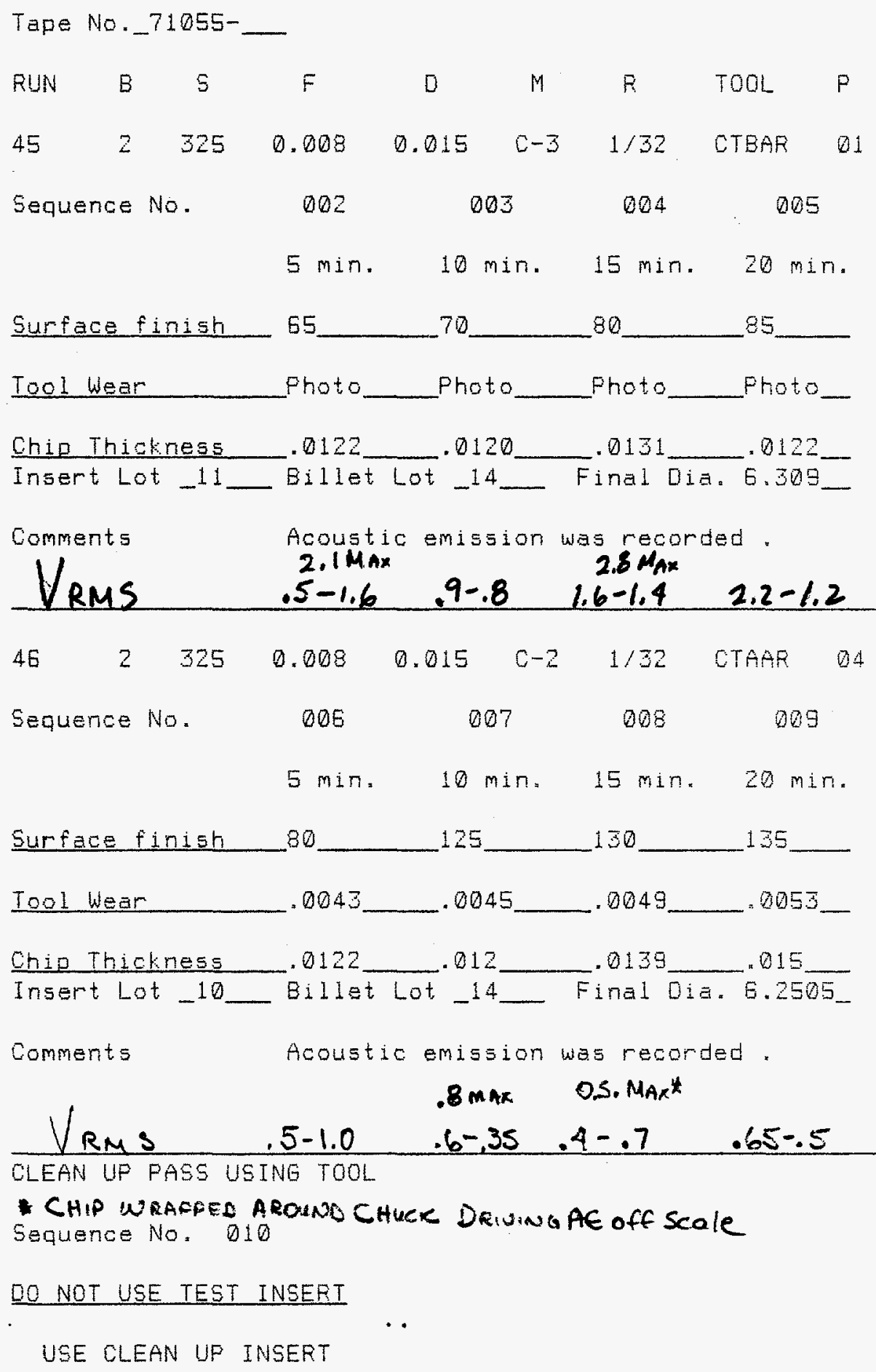

Sequence No.

$$
\square 05
$$$$
007
$$

008

009

$5 \mathrm{~min}$.

10 min.

$15 \mathrm{~min}$.

$20 \mathrm{~min}$.

Surface finish 80 125 130 135

Iool Wear .0043 .0045 .0049 .0053

Chip Thickness .0122 .012

Insert Lot -10 Billet Lot 14 .0139 .015

Comments Acoustic emission was recorded.

$.8 \operatorname{mar} \quad$ 0.5. MAR

VRMS $.6-35 \quad .4-.7$ $.65-.5$

CLEAN UF PASS USING TOOL

CHIP Wraffed AROAnO CHUCK DRiving AE off Scole
Sequence No. DIO

DO NOT USE TEST INSERT

USE CLEAN UP INSERT 


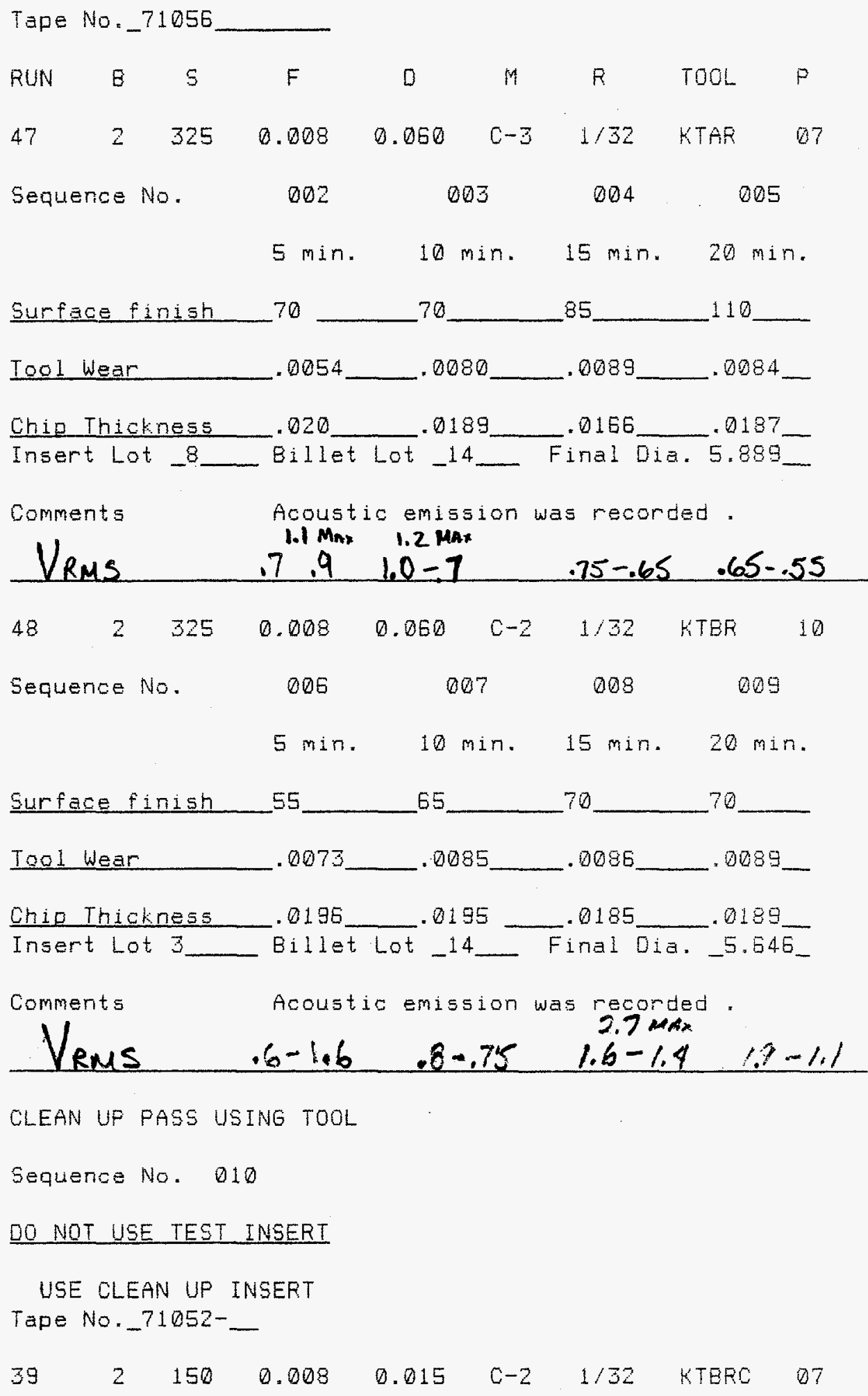


Appendix D ..

ILLUSTRATIONS 


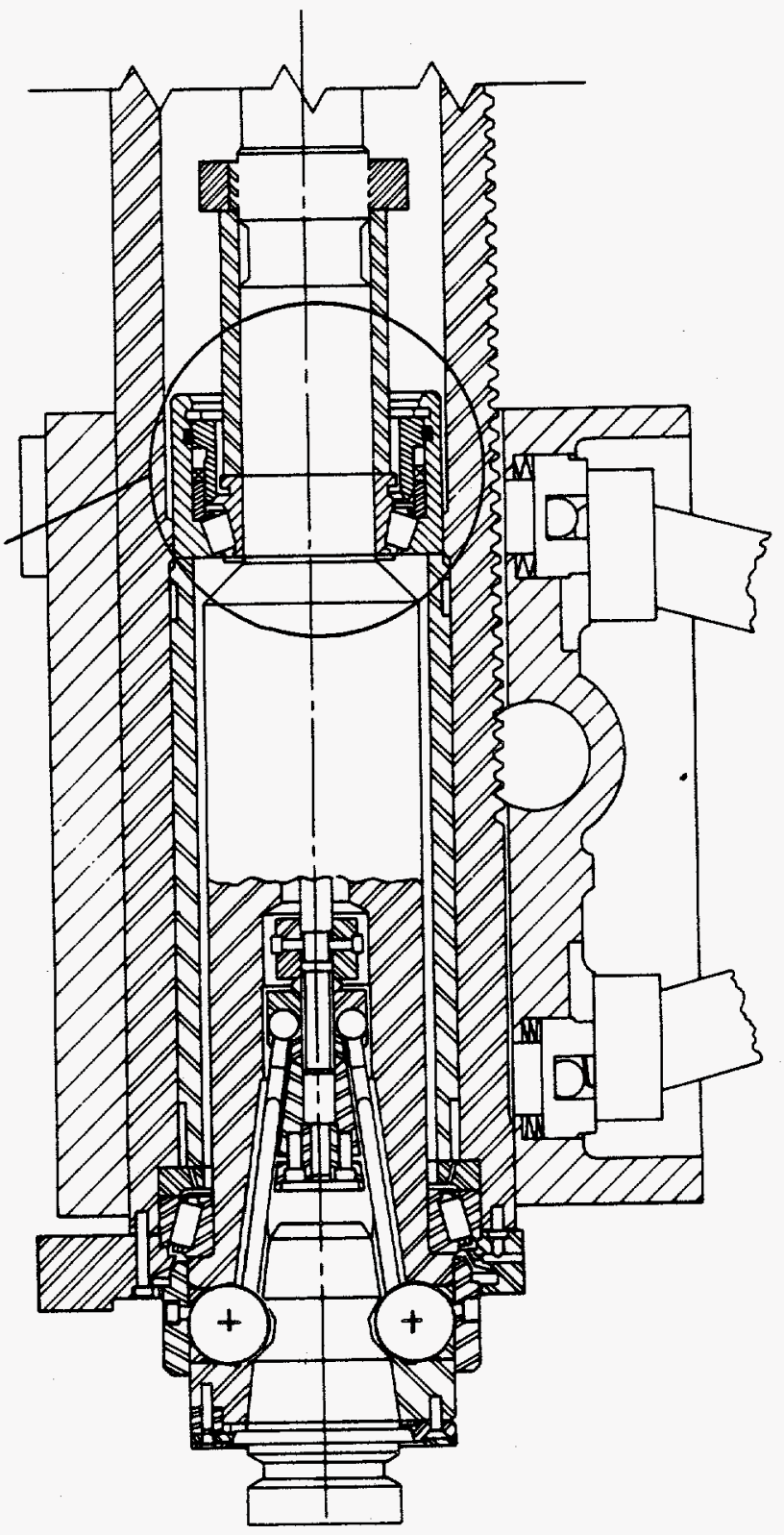

Figure D-1. Monarch Spindle Construction Showing AE Path 


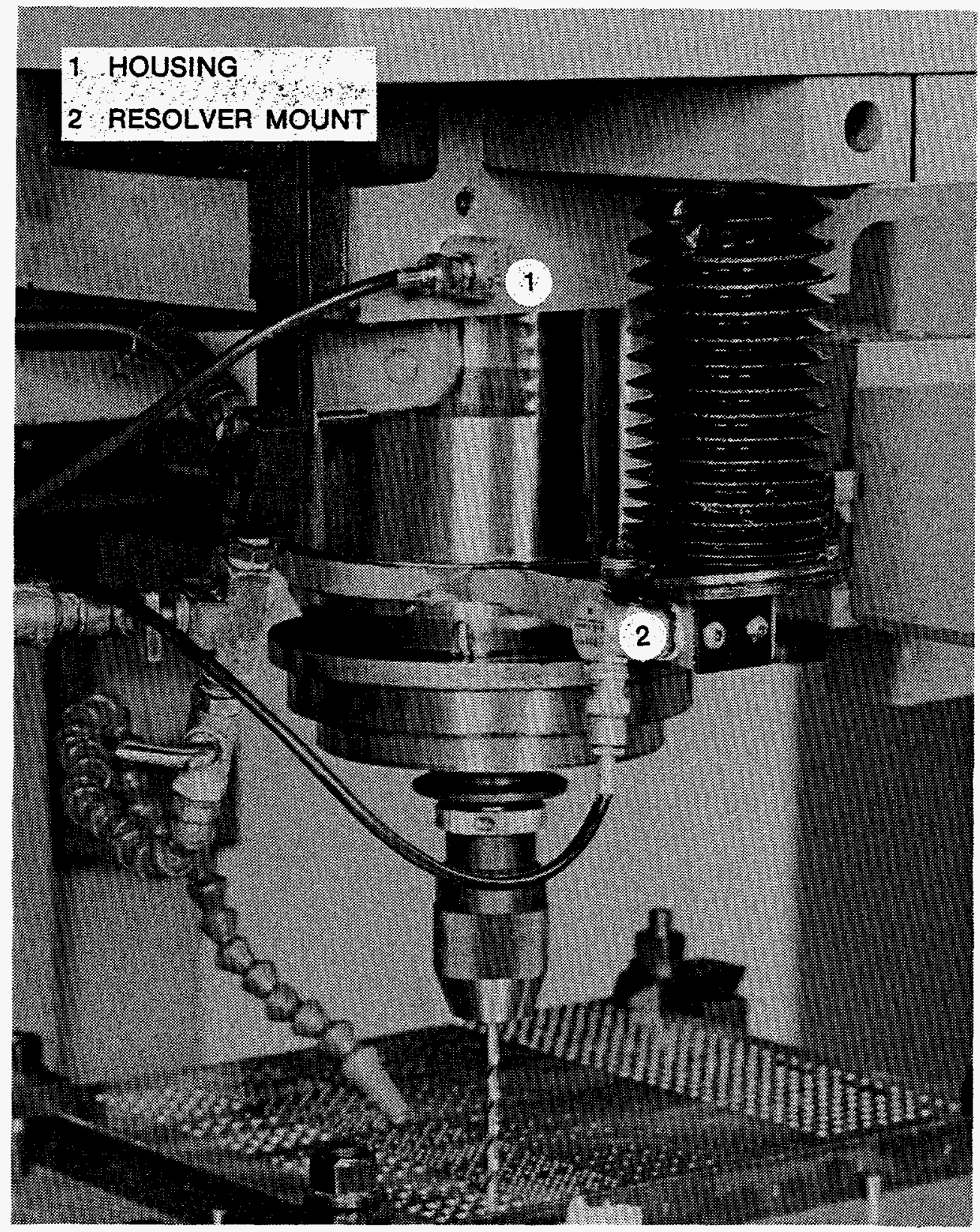

Figure D-2. Transducer Location on Courtland Mill 


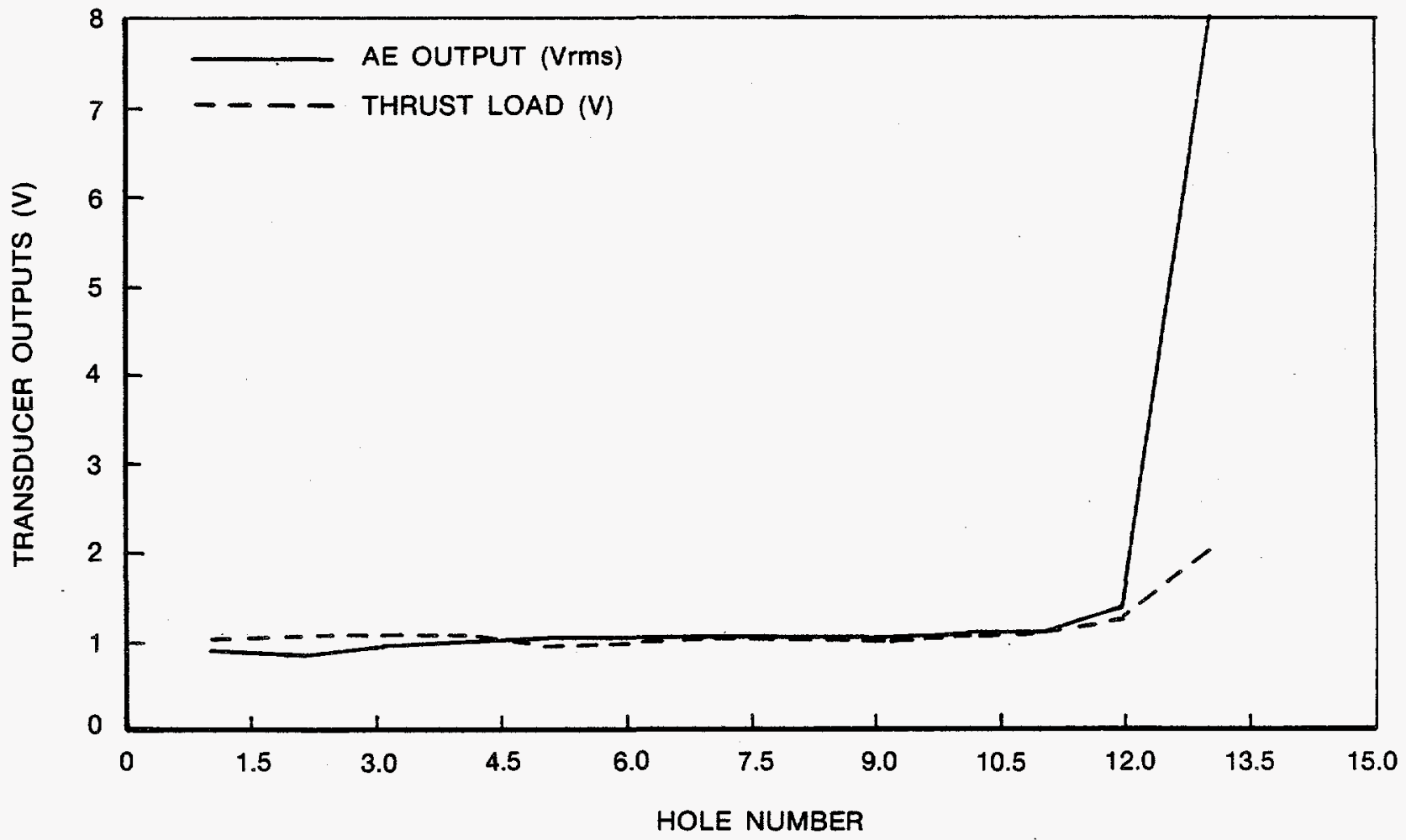

Figure D-3. Acoustic Emission and Thrust Load Output Versus Number of Holes Drilled AE Transducer on Resolver Mount 


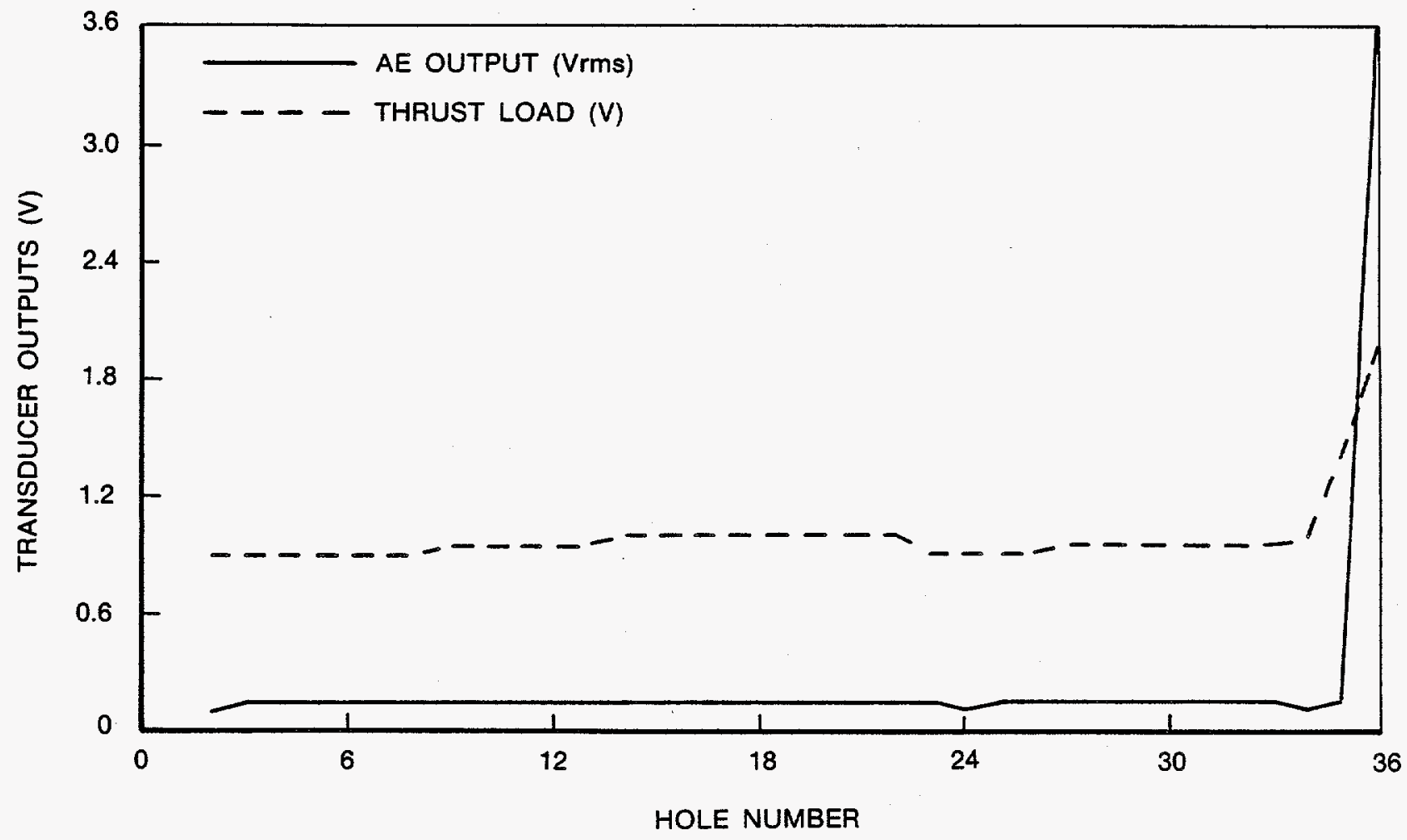

Figure D-4. Acoustic Emission and Thrust Load Output Versus Number of Holes Drilled AE Transducer on Spindle Head 


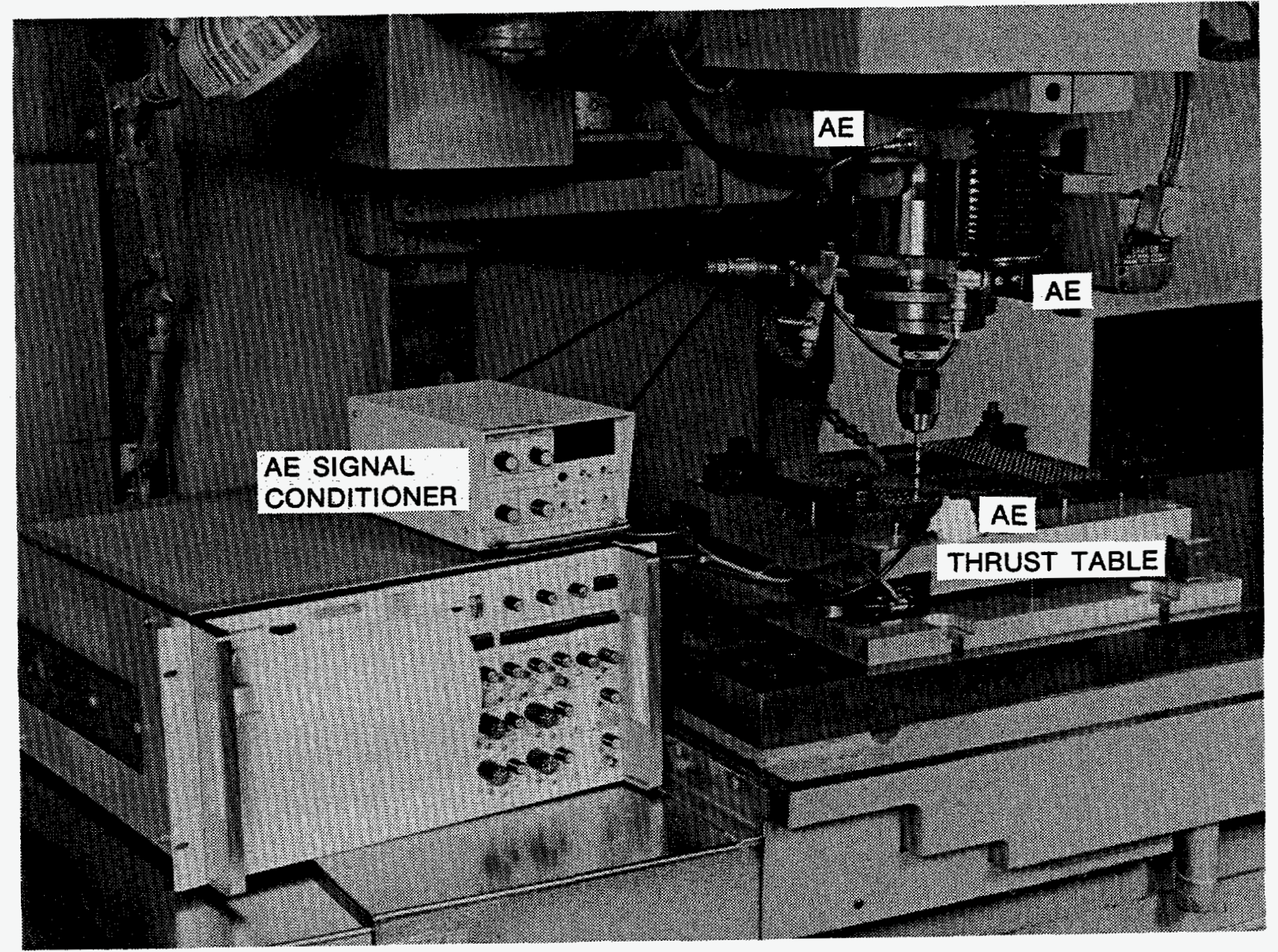

Figure D-5. Transducer Location on Thrust Table 


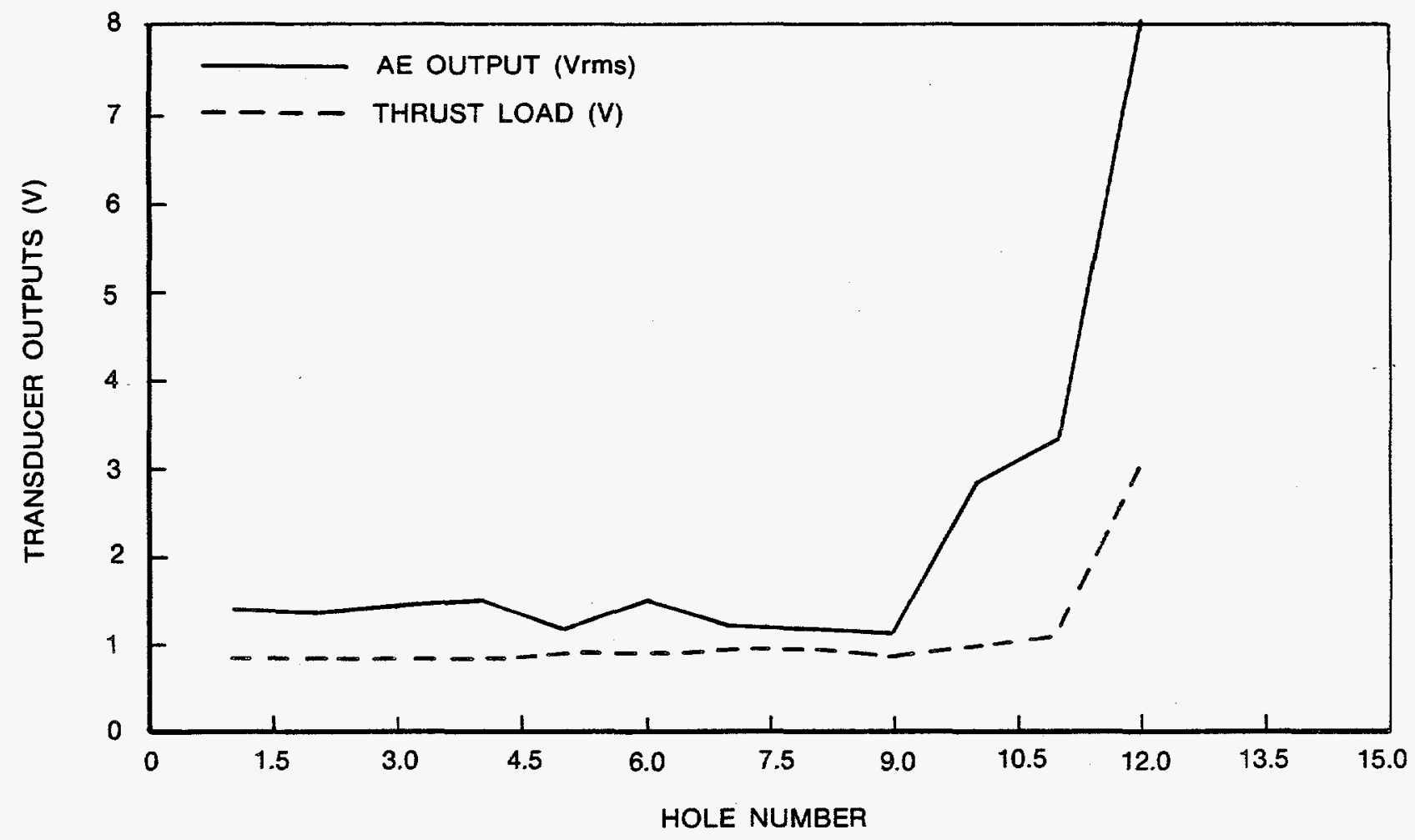

Figure D-6. Acoustic Emission and Thrust Load Output Versus Number of Holes Drilled AE Transducer on Thrust Table 


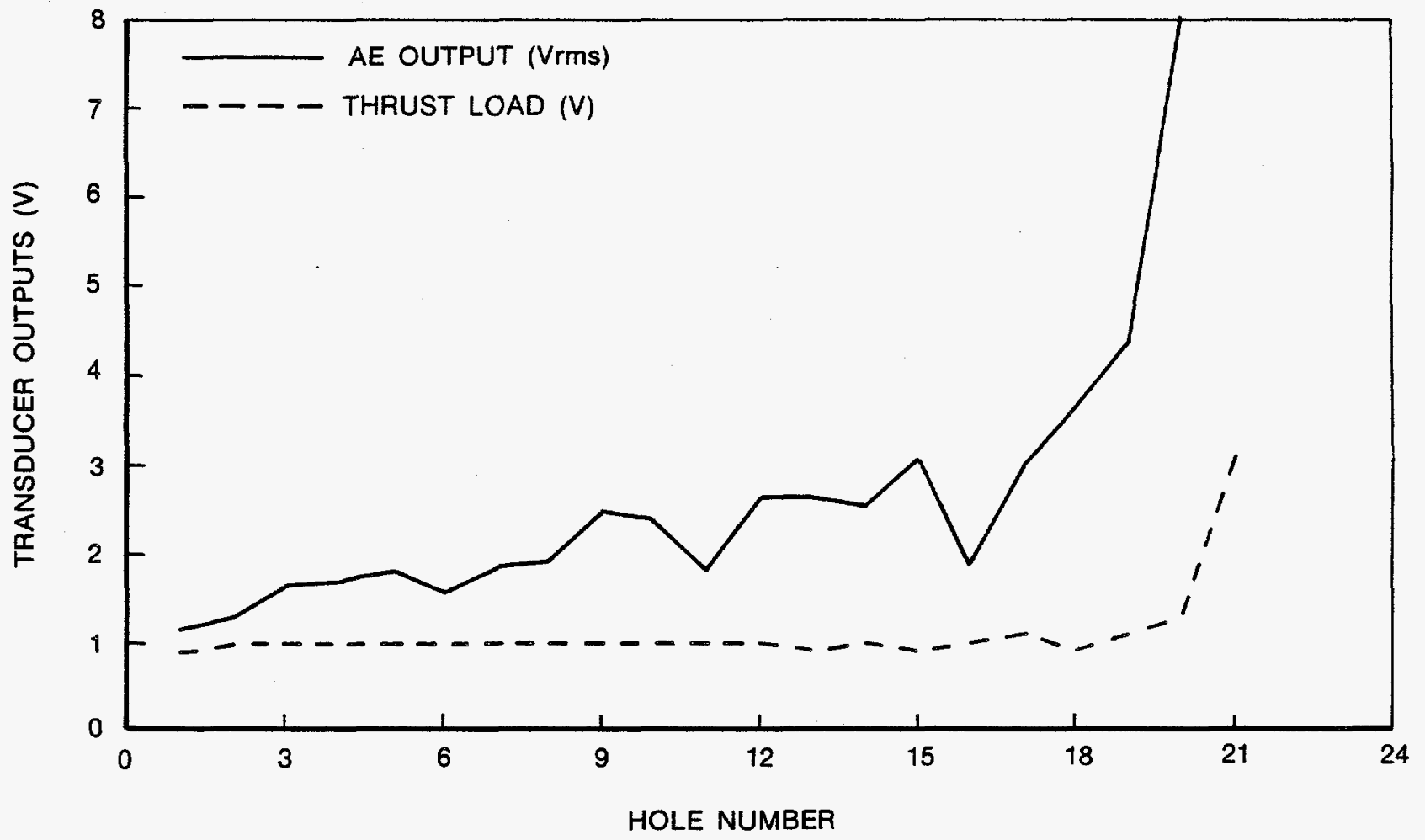

Figure D-6 Continued. Acoustic Emission and Thrust Load Output Versus Number of Holes Drilled AE Transducer on Thrust Table 


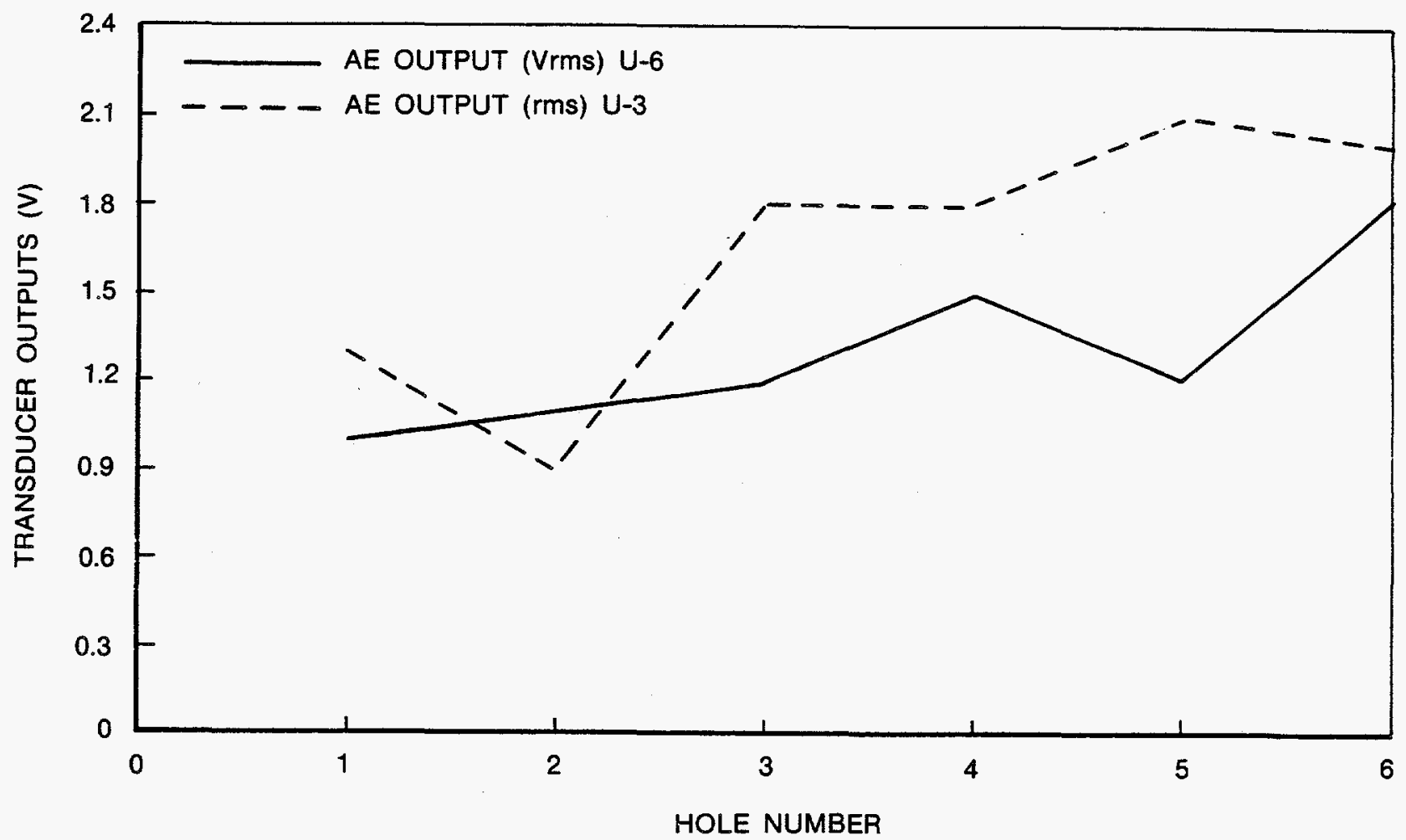

Figure D-7. Acoustic Emission Output Versus Distance From Transducer (Odd-Near, Even-Far) AE Transducer on Thrust Table 


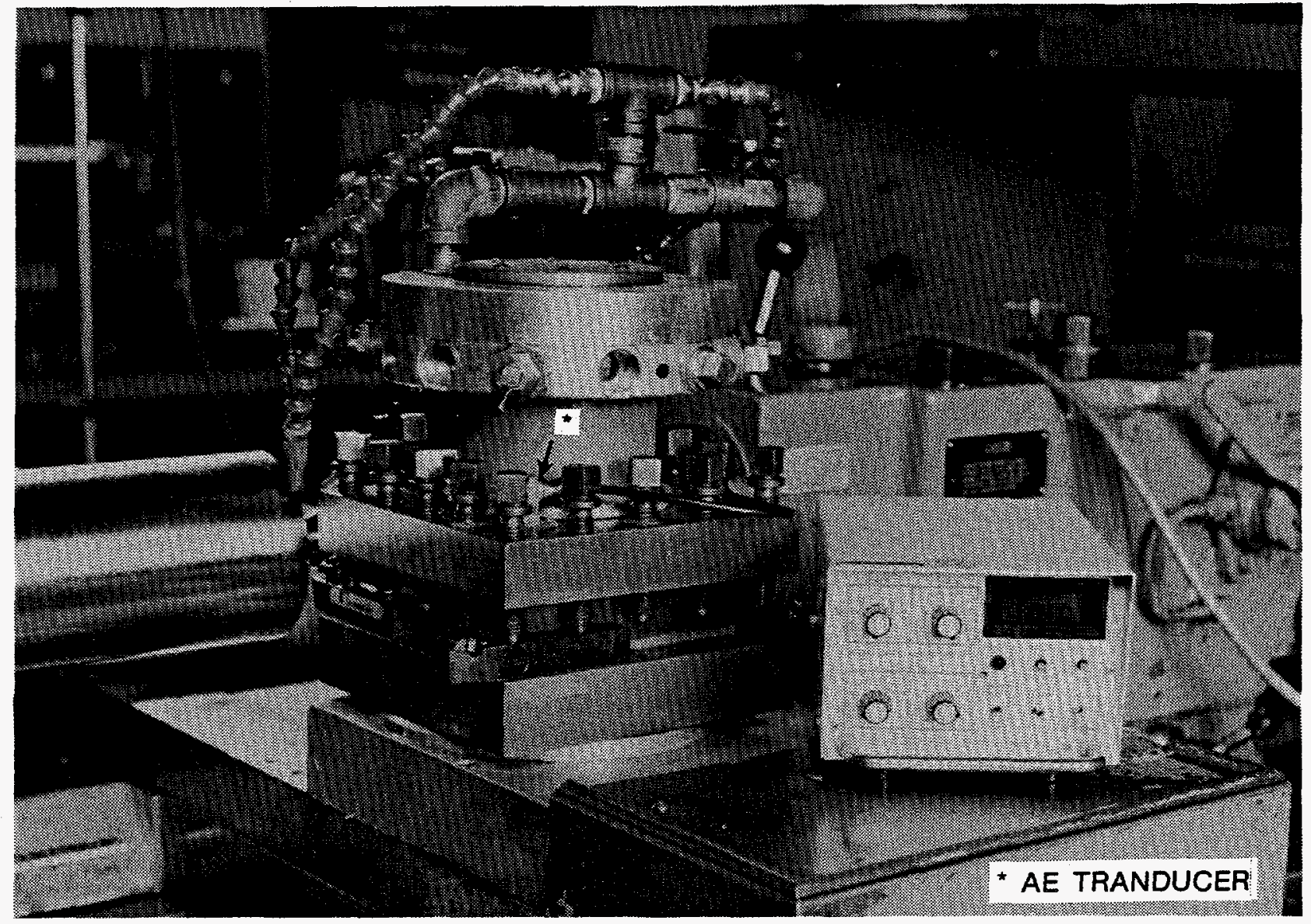

Figure D-8. Transducer Location on American Lathe 